\title{
Mestská politická elita v Nitre v 30. a 40. rokoch 20. storočia. K otázke personálnych zmien s dôrazom na postavenie starostu Františka Mojta ${ }^{1}$
}

\author{
MARTIN HETÉNYI
}

\section{Filozofická fakulta Univerzity Konštantína Filozofa v Nitre}

The urban political elite in Nitra in the 1930s and 1940s. On the issue of personnel changes with emphasis on the position of Mayor František Mojto

Abstract: The consequences that usually result from crises of regimes and changes in political-economic systems are the exchange of power political elites. This happened several times in Slovakia in the first half of the $20^{\text {th }}$ century. From the central level of politics, the changes have been affected in the next stages of its lower grades - regions, towns and municipalities. The contribution submitted focuses on the 1930s and 1940s, when an authoritarian popular regime with totalitarian elements was established in Slovakia. In a case study of the long-time leader of Nitra, František Mojto, the author tries to outline the legitimacy and agility of the Nitra political elite. On his example, we can explicitly observe remarkable ways in the process of handing power over or cooperation of political actors at all levels of the state and party apparatus. At the same time, his case signals to us the continuity of personnel with the democratic Czechoslovak Republic, which, however, was rather the exception at the national level as a rule. Keywords: Municipal Government, Nitra, Elite, $30^{\text {th }}$ and $40^{\text {th }}$ years of $20^{\text {th }}$ century.

DOI: https://doi.org/10.24040/ahn.2021.24.01.19-51

Jedným z celého súboru dôsledkov, ktoré zvyčajne prinášajú krízy režimov a zmeny politicko-ekonomických systémov býva menšia či väčšia transformácia mocenských politických elít. V prvej polovici 20. storočia sa tak na Slovensku udialo viackrát - po vzniku Československej republiky (d'alej ČSR) v roku 1918, po nástupe nedemokratického režimu Hlinkovej slovenskej l'udovej strany (d'alej HSL'S) v roku 1938, po oslobodení Československa v roku 1945 a po nástupe komunistického totalitného režimu po februári 1948. Z centrálnej úrovne politiky sa zmeny dotkli v d'alších fázach jej nižších stupňov - regiónov, miest a obcí. Predložený príspevok sa zameriava na 30. roky a 40. roky, kedy bol na Slovensku nastolený autoritatívny l'udácky režim s totalitnými prvkami. Proces úplného uchopenia moci l’udákmi bol inšpirovaný obdobnými procesmi

1 Táto práca bola podporená Agentúrou na podporu výskumu a vývoja na základe zmluvy č. APVV-17-0199. Štúdia vznikla tiež v rámci riešenia projektu KEGA č. 035UKF-4/2021. 


\section{Martin Hetényi}

v Tretej ríši a fašistickom Taliansku. ${ }^{2} \mathrm{~K}$ pochopeniu jeho celistvej pôsobnosti nestačí len pohl'ad na legislatívnu oblast', ale aj na praktickú realizáciu politiky, a to aj v prostredí degradujúcej samosprávy. Štúdium životných osudov historických osobností, ktoré po obsadení vplyvných postov začali disponovat' mocou a determinovat' smerovanie vývoja spoločnosti má svoj primárny význam v úsilí produktívne kompletizovat' historiografickú tvorbu. Poznanie dobovej spoločnosti a komplexného pochopenia podstaty politických režimov, ktoré sa v moderných dejinách na Slovensku postupne ukotvili je zase konkrétnym predpokladom determinovania súčasnej spoločensko-politickej a výchovno-vzdelávacej oblasti.

Elity sú žiadanou témou politológie, sociológie, filozofie i histórie. Podl'a jedného z nestorov slovenskej historiografie, L'ubomíra Liptáka, bolo 19. a 20. storočie v slovenských dejinách poznačené zmenami režimov a diskontinuitami. ${ }^{3}$ Predstava, že ruptúra politicko-ekonomických systémov automaticky prináša aj radikálnu zmenu politických a spoločenských elít na všetkých úrovniach nie je racionálna, a nie vždy sa staré elity odstavili na vedl'ajšiu kol'aj. V politickom myslení je elitizmus odborným termínom vychádzajúcim najmä z diela talianskych sociológov Gaetana Moscu a Vilfreda Pareta. Možno pri tom vychádzat' z Moscovej definície elít stotožnených s vládnucou triedou a z Paretovho poňatia „cirkulácie elít". ${ }^{4}$ Podl'a d'alšieho teoretika elít Roberta Michelsa však nemožno ani pri zásadných revolučných zmenách hovorit’ o úplnej výmene elít. Čast' pôvodnej „panujúcej triedy“ sa vždy presadí aj v novom režime a adaptuje sa na nové podmienky, pričom si uchová svoj status mocenskej elity. ${ }^{5}$ Štúdia vychádza z vymedzenia užšieho pojmu mestská politická elita, ktorú v duchu spomínaných teoretických koncepcií bližšie

\footnotetext{
2 Bližšie pozri: NIŽŇANSKÝ, Eduard: Zmocnenie sa vlády HSL’S v roku 1938/39 na Slovensku a „Machtergreifung“ 1933/34 v Nemecku. In: NIŽŇANSKÝ, Eduard: Nacizmus, holokaust, slovenský štát. Bratislava : Kalligram, 2010, s. 14-44. K totalitám bližšie pozri napríklad: ARENDT, Hannah: The Origins of Totalitarianism. New York : World Publishing Co., Meridian Books, 1958. 576 s.; ARON, Raymond: Demokracie a totalitarismus. Brno : Atlantis, 1999. 224 s.; POPPER, Karl R. The Open Society and its Enemies. Volume II: The High Tide of Prophecy: Hegel, Marx, and the Aftermath. New York and Evanston : Harper \& Row, Harper Torchbooks, $1967.420 \mathrm{~s}$.

${ }^{3}$ LIPTÁK, Lubomír: Storočie dlhšie ako sto rokov. Bratislava : Kalligram, 2011, s. 133-138.

${ }^{4}$ MOSCA, Gaetano: The Ruling Class. New York - London : McGraw-Hill Book Company, 1939. 514 s. Pre otázky elít sú dôležité aj iné klasické sociologické práce, najmä Maxa Webera, ktorý konceptuálne vymedzil politickú moc ako schopnost' presadit' v sociálnych vzt'ahoch vlastnú vôlu. WEBER, Max: Wirtschaft und Gesellschaft. Tübingen : Mohr, 1922, 868 s. WEBER, Max: Metodologie, sociologie a politika. Praha : OIKOYMENH, 2009. 351 s.; PARETO, Vilfredo: The Mind and Society. III. Theory of Derivations. London : Jonathan Cape Thirty Bedford Square, 1935. PARETO, Vilfredo: The Circulation of Elites. In Theories of Society. Foundations of Modern Sociological Theory. Volume I. New York : The Free Press of Glencoe, 1961, s. 551-558. ${ }^{5}$ MICHELS, Robert: Political Parties. A Sociological Study of the Oligarchical Tendencies of Modern Democracy. New York : Heart's International Library Company, 1915, s. 365-392,
} 
Mestská politická elita v Nitre v 30. a 40. rokoch 20. storočia ...

charakterizovali aj súčasní slovenskí historici Martin Pekár a Zuzana Tokárová ako relatívne malú súdržnú sociálnu skupinu členov zdiel'ajúcich spoločné hodnoty a záujmy. Príslušníci takejto skupiny koncentrujú vo svojich rukách politickú autoritu umožňujúcu ovplyvňovat' chod i d'alšie smerovanie miestneho spoločensko-politického vývoja v súlade $s$ vlastnými záujmami. Oproti nej stojí početný zástup politicky pasívnych obyvatel'ov mesta, ktorí sú vlastne eliminovaní z procesu rozhodovania a sú nielen riadení, ale aj kontrolovaní elitou. ${ }^{6}$

Rozhranie celoštátnej politiky v sledovanom období súhrnne patrí k relatívne dobre prebádaným oblastiam. ${ }^{7}$ Regionálnej politike v kontexte zmien vo verejnej správe sa v posledných dekádach venovali napríklad Martin Pekár, Ondrej Podolec, Pavol Tišliar, Miroslav Palárik, Alena Mikulášová, Karol Janas, Veronika Szeghy-Gayer a i. ${ }^{8}$ Bádanie presunu

400-404. ŠOLTÉS, Peter - VÖRÖS, László: „Odt’até ruky“? Kontinuity a diskontinuity politických a spoločenských elít na Slovensku v 19. a 20. storočí. In: Forum Historiae, 2018, roč. 12, č. 1, s. 3. Dostupné na internete: http://www.forumhistoriae.sk/sk/tema/elity-na-slovensku-v-19-20-storoci.

${ }^{6}$ PEKÁR, Martin - TOKÁROVÁ, Zuzana: Výmeny mestských politických elít na Slovensku po páde medzivojnovej československej demokracie (Prešov, 1938 - 1944). In: Studia Historica Nitriensia, 2019, roč. 23, č. 1, s. 144-157.

${ }^{7}$ Z novších prác možno spomenút': BAKA, Igor: Politický systém a režim Slovenskej republiky v rokoch 1939 - 1940. Bratislava : Vojenský historický ústav, 2010. 322 s.; FERENČUHOVÁ, Bohumila - ZEMKO, Milan a kol.: V medzivojnovom Československu 1918 - 1939. Bratislava : Veda, 2012. 542 s.; HRADSKÁ, Katarína - KAMENEC, Ivan: Slovenská republika 1939 1945. Bratislava : Veda, 2015. 480 s.; TOKÁROVÁ, Zuzana: Slovenský štát : Režim medzi teóriou a politickou praxou. Košice : Univerzita Pavla Jozefa Šafárika v Košiciach, 2016. 272 s. Problematike l'udáckeho režimu sa venovali aj zahraniční autori vo viacerých hodnotných prácach, napríklad: HOENSCH, Jörg K.: Die Slowakei und Hitlers Ostpolitik. Hlinkas Slowakische Volkspartei zwischen Autonomie und Separation 1938 - 1939. Köln - Graz : Böhlau Verlag, 1965. 390 s.; TÖNSMEYER, Tatjana: Kollaboration als handlungsleitendes Motiv? Die slowakische Elite und das NS-Regime. In: Kooperation und Verbrechen. Formen der Kollaboration in Südost- und Osteuropa 1939 - 1954. Göttingen : Wallstein, 2003, s. 25-54. JELINEK, Yeshayahu A.: The Parish Republic : Hlinka's Slovak People's Party 1939 - 1945. New York London, 1976. 206 s. WARD, James Mace. Priest, Politician, Collaborator : Jozef Tiso and the Making of Fascist Slovakia. Ithaca - New York : Cornell University Press, 2013. 376 s.

${ }^{8}$ Bližšie pozri napríklad: JANAS, Karol: Reforma verejnej správy na Slovensku v roku 1940 a jej dopad na okres Piešt'any. In: Balneografický spravodajca, 2001 - 2002, roč. 38, s. 27 34. JANAS, Karol: Reforma verejnej správy na Slovensku v roku 1940 s osobitným zameraním na obnovenie Župného úradu v Bratislave. In: Bratislava : Zborník mestského múzea v Bratislave, 2003, roč. 15, s. 115-120. JANAS, Karol: Rozklad župného zriadenia v rokoch 1944 - 1945. In: Slovenská republika 1939 - 1945 očami mladých historikov IV. Banská Bystrica : Katedra histórie FHV UMB a Ústav vedy a výskumu UMB, 2005, s. 352-360. PALÁRIK, Miroslav - MIKULÁŠOVÁ, Alena: Revízia znakov, symbolov, pamätníkov a sôch v období autonómie a Slovenskej republiky 1938 - 1945 : Príklad mesta Nitra. In: Historický časopis, 2018, roč. 66, č. 3, s. 523-546. PEKÁR, Martin: Politický systém prvej SR so zretel'om na postavenie regiónu (štruktúrna analýza s príkladom Šarišsko-zemplínskej župy). In: Regionálne dejiny a dejiny regiónov. Prešov : Ročenka Katedry dejín FHPV PU, 2004, s. 195-212. PODOLEC, Ondrej: Postavenie obecnej samosprávy na Slovensku v rokoch 1938 - 1945. In: 


\section{Martin Hetényi}

moci na regionálnej či miestnej úrovni a následných sociálno-politických dôsledkov je napriek tomu v kvalitatívne horšom stave, ked'že sa značná čast' autorov vedeckých publikácií spravidla obmedzuje na jednoduchý popis bez ambície vzniknuté zmeny skúmat' do híbky. ${ }^{9}$ Tento jav konštatujú aj Martin Pekár a Zuzana Tokárová v prípadovej štúdii z roku 2019, ktorá detailne analyzuje mechanizmus výmeny miestnej politickej elity po 6. októbri 1938 a 14 . marci 1939 v prostredí samosprávy mesta Prešov. Autori zároveň ponúkajú model, akým spôsobom uchopit' pôsobenie orgánov mesta a celý rad sprievodných javov príznačných pre personálne rošády v podmienkach (nielen) nedemokratického režimu. ${ }^{10}$ Pre poznanie problematiky elít na Slovensku sú tiež dôležité štúdie v monotematickom prvom čísle vedeckého časopisu Slovenskej akadémie vied Forum Historiae z roku $2018^{11}$ a kolektívna monografia Elity a kontraelity na Slovensku v 19. a 20. storočí : Kontinuity a diskontinuity. ${ }^{12}$

Analýza elít je v značnom rozsahu realizovaná pri štúdiu autokratických a totalitných režimov. Do schém poznávania legitimity a aktivít politických lídrov zapadá aj prípadová štúdia o dlhoročnom predstavitel'ovi mesta Nitra Františkovi Mojtovi, ktorý si do kresla starostu zasadol v roku 1932 a na čele mesta sa i po rôznych turbulenciách udržal až do konca druhej svetovej vojny. V rámci analýzy odbornej publicistiky je potrebné konštatovat', že o tejto osobnosti existujú zväčša sporadické texty viažuce sa k jej medzivojnovému obdobiu, pričom bližšia zmienka o pôsobení vo funkcii vládneho komisára po roku 1940 zatial' absentovala. Jedinými novšími prácami z rúk profesionálnych historikov je kapitola Nitra v období totality (1939 - 1990) v syntetizujúcej publikácii Dejiny

\footnotetext{
Historický časopis, 2003, roč. 51, č. 4, s. 647-668. SZEGHY-GAYER, Veronika: Personálna kontinuita politickej elity v Košiciach po Viedenskej arbitráži. In: Forum Historiae, 2018, roč. 12, č. 1, s. 129-140. Dostupné na internete: http://www.forumhistoriae.sk/sk/tema/ elity-na-slovensku-v-19-20-storoci. TIŠLIAR, Pavol: Okresná správa na Slovensku počas I. ČSR. In: Historica XLVI, 2005, roč. 46, s. 147-185. TIŠLIAR, Pavol: Náčrt postavenia okresných úradov na Slovensku počas krajinského zriadenia (1928 - 1939). In: Historica XLV, 2002, roč. 55, s. 219-223. TIŠLIAR, Pavol: K otázke fungovania štátnej správy na Slovensku v rokoch 1938 až 1945. In: Slovenská republika 1939 - 1945 očami mladých historikov II. Trnava : Mercury, 2003, s. 55-81.

${ }^{9}$ Bližšie pozri: BYSTRICKÝ, Valerián: Politické rozvrstvenie spoločnosti na Slovensku vo svetle obecných volieb roku 1938. In: BYSTRICKÝ, Valerián: Od autonómie k vzniku Slovenského štátu. Výber zo štúdií. Bratislava : HÚ SAV, 2008, s. 120-137. PEKÁR, Martin: Zlomové udalosti 20. storočia v syntézach dejín vybraných slovenských miest. Poznámky k trendom vo výskume. In: Jak psát dějiny velkých měst? Brno : Statutární město Brno - Archív města Brna, 2016, s. 120-131.

${ }^{10}$ PEKÁR, M. - TOKÁROVÁ, Z.: Výmeny mestských politických elít, s. 146.

11 Dostupné na internete: http://www.forumhistoriae.sk/sk/tema/elity-na-slovensku-v19-20-storoci.

12 Kol. autorov: Elity a kontraelity na Slovensku v 19. a 20. storočí : Kontinuity a diskontinuity. Bratislava : Veda, 2019. 572 s.
} 
Nitry. Od najstarších čias po súčasnost' z roku $1998^{13}$ a monografia City and Region Between Backdrops of Totality s podtitulom Images from Life in the Slovak Republic (1939 - 1945) illustrated in the City of Nitra and its Surrounding z roku 2018. ${ }^{14}$ Inšpiratívna je aj najnovšia štúdia Martina Pekára, ktorý nadviazal na spomínanú prácu o Prešove a uskutočnil aj empirickú komparáciu politických elít medzi Nitrou a Prešovom v rokoch 1938 - $1940 .{ }^{15}$ Preskúmaná informačná báza pozostávajúca z archívnych materiálov, súdobej tlače a relevantnej odbornej literatúry, umožnila pohl'ad do zákulisných dejov miestnej politiky. Nezanedbatel'ná čast' poznávania je venovaná jeho prejavom a konkrétnym aktivitám, ako aj rôznym oficiálnym i neoficiálnym dokumentom, ktoré obsahoval jeden z podstatných archívnych zdrojov - spis z povojnového súdneho procesu. Skrz historickú biografiu tejto osobnosti bolo možné prispiet' k ilustrovaniu viacerých zložitých javov sprevádzajúcich danú dobu a vybrané mesto. Tam, kde sa dá skúmat' viac zástupcov elít, môžu teoretické analýzy sledovat' ich vzájomné spoločenské, organizačné, ideologické či ekonomické prepojenie, stupeň súdržnosti elít, vplyv presvedčenia elít na politiku a pod.

František Mojto sa narodil 10. októbra 1885 v Pruskom, dedinke pri Ilave. Po l'udovej škole, ktorú navštevoval v rodisku, študoval najprv na gymnáziu v Trenčíne, a potom vyššie ročníky v Nitre, kde aj zmaturoval. Ako človek vychovaný v silne náboženskom a pacifistickom ovzduší si vybudoval odmietavý vzt'ah k vojnám a k ozbrojeným zložkám. Na vojenčinu, vzhl'adom na svoje študijné záujmy, nikdy nenarukoval. Vo vzdelávaní pokračoval štúdiom na katolíckej Teologickej fakulte v Budapešti, no ukončil ho už v druhom ročníku. Potom nastúpil do zamestnania ako učitel' v Dubnici nad Váhom a súbežne si dopĺňal vzdelanie na Učitel'skom ústave v Spišskej Kapitule, kde absolvoval aj skúšku z hudobnej teórie a hry na organe. V rokoch 1906 až 1908 pôsobil vo Vysočanoch, obci ležiacej pri Bánovciach nad Bebravou, d’alšie dva roky v Kolačíne pri Dubnici nad Váhom. Potom prežil takmer 11 rokov v Čadci, kde ako hudobník kreoval a viedol cirkevný spevokol, s ktorým účinkoval pri

\footnotetext{
${ }^{13}$ NAGY, Zoltán - SLNEKOVÁ, Veronika: Nitra v období totality (1939 - 1990). In: FUSEK, Gabriel - ZEMENE, Marián R. (eds.). Dejiny Nitry od najstarších čias po súčasnost'. Nitra : Mesto Nitra, 1998, s. 325-348.

${ }^{14}$ PALÁRIK, Miroslav - MIKULÁŠOVÁ, Alena - HETÉNYI, Martin - ARPÁŠ, Róbert: The City and Region Against the Backdrop of Totalitarianism : Images from the Life in the Slovak Republic (1939-1945), Illustrated by the City of Nitra and Its Surroundings. Berlin : Peter Lang, 2018. $280 \mathrm{~s}$.

15 PEKÁR, Martin: Replacement of Municipal Political Elite as a Tool for Seizing Power and Consolidating an Authoritarian Regime in Slovakia 1938 - 1940. In: The City and History, 2020, roč. 9, č. 1, s. 93-111. Dostupné na internete: https://www.upjs.sk/public/media/23562/CaH_2020_1_articles_pekar.pdf.
} 


\section{Martin Hetényi}

rôznych príležitostiach. Približne v roku 1920 prešiel na nové pôsobisko do Nových Sadov ned'aleko Nitry. Aj tu dokázal svoju činorodost' založením spevokolu, s ktorým vystúpil aj 13. februára 1921 v programe známej slávnostnej vysviacky troch slovenských biskupov v Nitre. ${ }^{16}$

Do Nitry sa Mojto natrvalo nast'ahoval v roku 1922, teda v dobe dotvárania nových politických a spoločenských procesov. Nitra vstupovala do novej éry ako okresné mesto s približne dvadsat'tisíc obyvatel'mi a aj za prvej republiky si uchovávala agrárny charakter. Väčšina jej osadenstva sa živila prácou v pol'nohospodárstve s prevládajúcim zameraním na pol'nohospodárske podniky, remeslá a obchod. Ako pomerne vel'ký, no $\mathrm{v}$ celoštátnych reláciách nie výnimočný problém, ktorému v tomto období čelili predstavitelia mesta sa javila otázka nezamestnanosti. K d’alším naliehavým úlohám patrili otázky súvisiace $s$ kvalitou života, bývania a urbanizmu v meste, riešenie neustálych záplav, výstavba kanalizácie a vodovodnej siete, škôl, parkov či dláždenie ulíc. Hoci v Nitre pulzoval aj živý remeselný ruch a pribudli tu rôzne firmy a podniky (fabriky na spracovanie tabaku či výrobu tehál), mesto aj v d'alších desat'ročiach zostávalo dominantne pol'nohospodárskym, obchodným a finančným centrom juhozápadného Slovenska. Nitra sa zároveň ustálila ako jedno z najvýznamnejších kultúrnych centier a symbolických miest. Napriek početnej mad'arskej menšine, ktorej patrónmi boli svätci viažuci sa k Uhorskému štátu ${ }^{17}$, sa tu hlavne prostredníctvom cirkevných a iných záujmových kruhov vo všetkých sférach spoločenského, náboženského, osvetového a kultúrneho života rozvíjal cyrilo-metodský a pribinovský kult. ${ }^{18} \mathrm{~V}$ Nitre sa uskutočnili viaceré celoslovenské podujatia, ktoré odkazovali na vel'komoravské dejiny - napríklad už spomínaná biskupská vysviacka alebo Pribinove slávnosti. Do vývoja mesta ale nepriaznivo za-

\footnotetext{
16 PAŽITNÝ, Anton: František Mojto. In: Významné osobnosti Nitry. Nitra : Mesto Nitra, 1998, s. 101.

17 Pripomínanie si národných sviatkov v mad’arskom prostredí bolo silným prostriedkom ku konštruovaniu obrazu národnej homogenity a kontinuity mad'arského národného spoločenstva. MICHELA, Miroslav: Uhersko-mad’arské tradice. In: HÁJKOVÁ, Dagmar et al.: Sláva republice! Oficiální svátky a oslavy v meziválečném Československu. Praha : Nakladatelství Academia - Masarykův ústav a Archiv AV ČR, v. v. i., 2018, s. 431-468. MICHELA, Miroslav: „A Home Should Be a Home to All Its Sons“: Cultural Representations of Saint Stephen in Slovakia during the Interwar Period. In: HUDEK, Adam et al.: Overcoming the Old Borders: Beyond the Paradigm of Slovak National History. Bratislava : Prodama, 2013, s. 97-110. MICHELA, Miroslav: Percepcia svätého Štefana na Slovensku v medzivojnovom období. In: HLAVAČKA, Milan et al.: Pamět' míst, událostí a osobností: historie jako identita a manipulace. Praha : Historický ústav AV ČR, 2011, s. 218-243.

${ }^{18}$ Bližšie pozri MICHELA, Miroslav: Politizace cyrilometodějského kultu. In: HÁJKOVÁ, Dagmar et al.: Sláva republice! Oficiální svátky a oslavy v meziválečném Československu. Praha : Nakladatelství Academia - Masarykův ústav a Archiv AV ČR, v. v. i., 2018, s. 309-352. ŠKVARNA, Dušan - HUDEK, Adam: Cyril a Metod v historickom vedomí a pamäti 19. a 20. storočia na Slovensku. Bratislava : Historický ústav SAV, 2013. $161 \mathrm{~s}$.
} 
siahlo zrušenie Nitrianskej župy, prijatím zákona o krajinskom zriadení v roku 1928, čo spôsobilo odchod časti inteligencie, resp. bývalých župných úradníkov.

Úsilie mladého pedagóga vo vyučovacom procese smerovalo k pozdvihovaniu vedomostnej úrovne slovenčiny, čomu zodpovedala aj jeho pozornost' venovaná tvorbe národne ladených učebníc, teda nedostatkovým učebným pomôckam. ${ }^{19} \mathrm{~V}$ roku 1935 sa Mojto stal riaditel'om l'udovej školy na Zobore, vo vinohradníckej časti Nitry, kde pôsobil až do núteného ukončenia pedagogickej činnosti v roku 1945. Rozvinul pri tom spoluprácu so zväzom českých katolíckych učitel'ov, pričom bol dvakrát pozvaným prednášatel'om na ich kurzoch - v Trenčíne v roku 1937 a v českých Domažliciach v roku 1938. Svoju vitalitu prejavil aj v rámci spolkovej činnosti - bol funkcionárom Krajinského učitel'ského spolku, Zemského učitel'ského spolku, predsedom hasičského spolku. Od roku 1920 bol hlavným editorom mesačníka Slovenský učitel', od septembra 1944 do februára 1945 zodpovedným redaktorom dvojmesačníka Slovenský pedagóg. ${ }^{20}$

František Mojto obýval služobný byt v školskej bytovke v nitrianskej vinohradníckej časti Zobor. Mojto živil početnú rodinu z viacerých príjmov, staral sa o výdavky na štúdium svojich detí mimo domova, platil aj domácu pomocnicu. Bol ženatý s Ol'gou, manželom sa narodilo 11 detí, $\mathrm{z}$ nich dve zomreli $\mathrm{v}$ útlom veku. Ich domácnost' bola zariadená skromne zo staršieho nábytku. Jeho ročné príjmy predstavovali napríklad v roku 1934 presne 116363 korún (z toho učitel'ský, redaktorský a starostovský plat predstavoval 77388 korún, odmeny člena správnych rád hospodárskych podnikov 38975 korún). ${ }^{21}$ Jeho zárobok sa pohyboval zväčša v analogickej výške aj neskôr, čo ho zarad'ovalo do lepšie situovanej strednej sociálnej vrstvy.

Angažovanie sa Mojta v politickej oblasti začalo v roku 1918 jeho vstupom do Slovenskej l'udovej strany, neskôr premenovanej na Hlinkovu slovenskú l'udovú stranu. Od roku 1923 pôsobil v nitrianskom mestskom zastupitel'stve.22 Ako zástupca HSL'S sa v roku 1929 ocitol na

\footnotetext{
19 Ako prvé pripravil Názornú čítanku a učebnicu jazyka slovenského (1922), Šlabikár (1923) a Návod k novému šlabikáru (ako pomôcku pre učitel’ov). Spracoval aj d’alšie metodické príručky pre pedagógov. Roku 1928 vyšiel jeho Nový abecedár a o dva roky neskôr v spoluautorstve $\mathrm{s}$ Jánom Detrichom zemepis pre šiesty ročník pod názvom Vlast' a svet. Roku 1932 v spoluautorstve s Jánom Schulzom publikoval učebnicu Naša reč I. - VI. Šlo zaiste o oblúbené učebnice, ktoré boli expedované aj na slovenské školy do Juhoslávie. V roku 1940 vydal Hviezdičky - čítanku pre prvý ročník l’udových škôl a metodickú príručku pre učitel’ov Základný výcvik v čítaní. PAŽITNÝ, A.: František Mojto, s. 101-102.

${ }^{20}$ Slovenský národný archív (SNA), f. Národný súd (NS), šk. 3, TnL’ud 4/45-7.

${ }^{21}$ SNA, f. NS, šk. 3, TnLuud 4/45-6.

22 Pamätná kniha mesta Nitry I., s. 118.
} 


\section{Martin Hetényi}

jej volebnej kandidátke do najvyššieho zákonodarného zboru. Poslancom pražského parlamentu sa stal po Tukovej afére ${ }^{23}$, ked' HSL'S prežívala politickú krízu a v jej straníckych kruhoch bolo potrebné napravit' jej poškodené meno. V strane sa hlásili k tejto úlohe tzv. aktivisti, ku ktorým patril svojim politickým založením aj Mojto. Najschodnejšou cestou k tomu sa núkala kooperácia so Šrámkovou Československou stranou lidovou, ktorá by l'ahšie tolerovala aj autonomistický program HSL'S, ked’že stála za krajinským zriadením v českých krajinách. Čast' l'udákov si od toho sl'ubovala, že HSL'S by sa takýmto spôsobom mohla zapojit' do štátotvornej budovatel'skej práce. Týmto smerom sa niesla celá Mojtova publicistická a politická činnost' počas pôsobenia v pražskom parlamente i potom. Poslancom Národného zhromaždenia v Prahe bol v rokoch 1929 až 1935. V Národnom zhromaždení bol členom rozpočtového, sociálno-politického a kultúrneho výboru. $\mathrm{V}$ rozpravách najvyššieho zákonodarného orgánu vystúpil zväčša v otázkach vzt'ahujúcich sa k stavu školstva na Slovensku. V parlamentných výboroch pracoval podl'a neskorších svedeckých výpovedí konštruktívne a vecne, bez zbytočného stranícko-politického vyhrocovania, čo si na ňom cenili viacerí parlamentní a vládni činovníci, medzi nimi i sociálnodemokratický minister školstva Ivan Dérer. ${ }^{24}$

Materiál $\mathrm{z}$ povojnového súdneho procesu prezrádzal čo-to $\mathrm{z}$ jeho postojov k prvej ČSR. Podl'a neho mal mat' k tvorcom prvej republiky Tomášovi G. Masarykovi i Edvardovi Benešovi kladný prístup, rovnako si vo svojich prejavoch i v súkromných debatách ctil demokratický pluralitný systém medzivojnovej republiky. $V$ tlači sa sporadicky a kriticky dotkol aj bujnejúceho fašizmu. $\mathrm{V}$ súdnom spise sa $\mathrm{k}$ jeho pôsobeniu v Národnom zhromaždení nachádzajú rôznorodé informácie, napríklad o kritike vládnych agrárnikov, o kritickom článku o nacistickom režime v Nemecku po nástupe Hitlera k moci či o uverejňovaní poslaneckých vystúpení v straníckych novinách, čo nám však dáva len značne obmedzenú predstavu o jeho skutočnej parlamentnej praxi. ${ }^{25}$ Známa je aspoň jeho participácia na rôznych celoštátnych či celoslovanských podujatiach (účast' v československej delegácii k hrobu král'a Alexandra v Juhoslávii v októbri 1935, v deputácii československých učitel'ov u prezidenta Beneša, na unionistickom zjazde vo Velehrade v roku 1935 a i.). Po smrti Tomáša G. Masaryka viedol delegáciu Nitranov k jeho hrobu do Lán a podporoval výstavbu pamätníka významných

\footnotetext{
${ }^{23}$ HRUBOŇ, Anton: Alexander Mach. Radikál z povolania. Bratislava : Premedia, 2018, s. 77-90.

${ }^{24}$ SNA, f. NS, šk. 3, TnL’ud 4/45-7.

${ }^{25}$ SNA, f. NS, šk. 3, TnL'ud 4/45-6 a 7. Slovenský učitel', 1. 9. 1938, č. 1., s. 45.
} 
československých štátnikov v Nitre. ${ }^{26}$ Hoci Mojto zaiste nepatril k najvýraznejším lídrom vtedajšej politickej scény, jeho aktivity neunikli pozornosti významného slovenského intelektuála a politika Karola A. Medveckého. Stúpenec českých lidovcov v súkromnom liste z 28. júla 1932 ich vyzdvihol nasledovne: „Nemám Vás čest'osobne poznat', ale po tom, čo o Vašej váženej osobnosti počúvam, považujem Vás za povolaného chystat' chodníčky, ako by sa tí, ktorým záujem katolicizmu, Slovenska a Republiky našej skutočne na srdci leží, na celoštátnom základe dorozumeli a jednota sŕdc sa pripravovala. "27

Najvyšším orgánom miestnej samosprávy bolo volené obecné zastupitel'stvo - v Nitre po roku 1930 pozostávalo zo 42 poslancov. ${ }^{28}$ Vol'by do obecného zastupitel'stva (1923, 1927, 1931 a 193829) nasvedčovali, že Nitrania vo všeobecnosti inklinovali viac k socialistickým stranám, ktoré sl’ubovali odstránenie t’aživých povojnových problémov. Silné voličstvo mali aj politické strany mad'arskej menšiny, ktorú podporovali majetnejší obyvatelia a čast’ drobných živnostníkov a robotníkov mad'arskej národnosti. ${ }^{30}$ Značnú podporu krest'ansky orientovaného obyvatel'stva ${ }^{31}$ mala aj HSL'S, ktorá spájala riešenie hospodárskej otázky s riešením štátoprávneho postavenia Slovenska. Na politickej scéne medzivojnovej Nitry zaujali relevantné pozície štyri politické subjekty, ktorých programy najviac odzrkadl'ovali sociálnu, náboženskú a národnostnú skladbu miestneho voličstva: Krajinská krest’ansko-socialistická strana (najvýznamnejšia politická strana mad'arskej menšiny, d’alej KKSS), HSL'S, Československá sociálnodemokratická strana robotnícka (d'alej ČSSD) a Komunistická strana Československa (d’alej KSČ). ${ }^{32}$ Dokazujú to napokon aj výsledky parlamentných

\footnotetext{
26 SNA, f. NS, šk. 3, TnLuud 4/45-7.

27 SNA, f. NS, šk. 3, TnL'ud 4/45-8.

${ }^{28}$ Vel'kost' obecných zastupitel'stiev špecifikoval §9 zákona č. 75/1919 Zb.

${ }^{29}$ Roku 1935 sa vol'by neuskutočnili, ked’že zákon č. 122/1933 Zb. predížil volebné obdobie zo štyroch na šest' rokov, čím sa zosúladila dížka úradovania obecnej samosprávy s pôsobením okresných a krajinských zastupitel'stiev.

${ }^{30}$ Národnostné zloženie mesta pri sčítaní obyvatel'stva v roku 1938 pozostávalo z 18835 obyvatel'ov slovenskej, 1235 českej, 776 mad'arskej, 197 nemeckej, 24 ruskej, 21 pol'skej, 98 židovskej, 19 cigánskej a 120 inej národnosti. Pamätná kniha mesta Nitry II., s. 92.

${ }^{31}$ Podl'a sčítania l'udu z roku 1938 sa v Nitre prihlásilo ku katolíckej konfesii 16336 obyvatel'ov, k evanjelickej a. v. 451, k reformovanej 71, k československej a českobratskej 161, k židovskej viere 3976, k inému 169 a bez vyznania 151 obyvatel'ov. Pamätná kniha mesta Nitry II., s. 92.

32 V roku 1923 z ôsmich kandidujúcich strán získalo najviac Slovenská l'udová strana, Krajinská krest’ansko-socialistická strana a Židovská strana (Pamätná kniha mesta Nitry I., s. 118-120). Vo vol'bách v roku 1927 bolo poradie nasledovné: Krajinská krest'ansko-socialistická strana, koalícia Komunistickej strany Československa, Československej sociálnode-
} 


\section{Martin Hetényi}

volieb v medzivojnovom období, v ktorých spomínané strany obsadzovali v Nitre najvyššie priečky. ${ }^{33}$

Za prvej republiky sa na čele Nitry vystriedali viaceré osobnosti: riaditel' škrobárne Emil Šebesta (1922 - 1923), hudobník a účtovník Karol Cobori (1923 - 1931), advokát Vojtech Szilágyi $\left(1931\right.$ - 1932) ${ }^{34}$ a v roku 1932 zvolený pedagóg František Mojto. Starostovi, jeho námestníkom, obecnej rade a odborným komisiám patrila výkonná právomoc v meste. Tieto druhy orgánov volilo obecné zastupitel'stvo. Starosta disponoval exekutívnymi a regulatívnymi kompetenciami vymedzenými legislatívou (predovšetkým zákonom č. 75/1919 Zb. obsahujúcim volebný poriadok do obcí a novelou obecného zriadenia včlenenou do zákona č. 76/1919 Zb.).

Obecné vol'by 27. septembra 1931 nepriniesli podstatnejšiu zmenu, prvé miesta získali ČSSD, KKSS, KSČ a až na štvrtom mieste skončila HSL'S. ${ }^{35}$ Pri vol'bách starostu 7. novembra 1931 prvýkrát kandidoval na funkciu starostu Mojto, získal však len 16 hlasov. Za sociálneho demokrata Vojtecha Szilágyiho hlasovalo 26 poslancov. Mojtovi nevyšla ani kandidatúra za miestostarostu, pri rovnakom počte hlasov pre dvoch kandidátov (21) nasledovalo druhé kolo, v ktorom jeho protikandidát z Československej strany národno-socialistickej (d'alej ČSNS) Rudolf Kulišek získal o jeden hlas naviac. Druhým zástupcom starostu sa stal zástupca KKSS František Bárek. Do 16-člennej mestskej rady, ktorá nebola len poradným orgánom, ale disponovala vlastnými vyhradenými kompetenciami boli zvolení za ČSSD Matej Zachar, Samuel Meitner, za ČSNS Rudolf Šumichrast, za HSL'S Peter Rovnianek, František Mojto, za KKSS Július Jedlička, za Československú národnú demokraciu Dr. Jaroslav Svoboda, za Židovskú hospodársku stranu Samuel Tausig, za Československú stranu lidovú Jozef Bednárik, za KSČ Ján Dostál a Pavel Verdunič. ${ }^{36}$ Členmi rady sa automaticky stali aj starosta a jeho zástupcovia, rovnako ex offo aj mestský notár, ktorého menovalo ministerstvo vnútra a jeho úlohou bolo zabezpečovat’ kontakty so štátnou správou.

Dňa 4. apríla 1932 zomrel po t’ažkej chorobe starosta Szilágyi. Jeho skon vydláždil cestu nástupu Františka Mojta, ktorý bol do vedenia mesta 15 hlasmi zvolený 10. mája 1932. Jeho protikandidátovi, komunis-

mokratickej strany a Československej strany národnosocialistickej, až za nimi sa umiestnila HSL’S (Štátny archív v Nitre - ŠA NR, f. Mestský úrad v Nitre, č. 21/1931, zápisnice zastupitel'stva).

33 ŠA NR, f. Mestský úrad v Nitre, č. 218/1929 adm. Bližšie pozri: ZUBÁCKA, Ida: Nitra za prvej Československej republiky. Nitra : Univerzita Konštantína Filozofa, 1997, s. 48-49.

${ }^{34}$ Nastúpil do dočasnej funkcie po prekvapivom odstúpení Coboriho 7. júla 1931. Pamätná kniha mesta Nitry II., s. 34 .

35 ŠA NR, f. Mestský úrad v Nitre, č. 21/1931, zápisnice zastupitel'stva.

${ }^{36}$ Proti vol'be vedenia podala HSL’S námietku. Pamätná kniha mesta Nitry II., s. 41. 
tovi Štefanovi Dobrotinovi, odovzdalo hlas 8 poslancov. Vo vol'bách bola rozhodujúca dohoda a podpora početnejších straníckych klubov, najmä sociálnych demokratov. Hoci HSL'S, za ktorú Mojto kandidoval, nemala v Nitre v tom čase najsilnejšie zastúpenie, združením s inými stranami napokon dokázala v samosprávnych orgánoch získat' absolútnu väčšinu. Post zástupcov starostu obsadila ČSSD (Samuel Meitner) a KKSS (Július Jedlička). ${ }^{37}$

Zakrátko po nástupe do starostovského kresla sa v dejinách mesta stali povestnou udalost'ou celoštátne Pribinove oslavy, do organizácie ktorých sa zapojil i samotný Mojto. Konali sa v augustových dňoch roku 1933 a napriek snahám Mojta a väčšiny organizátorov o apolitický a náboženský priebeh sa zvrhli a spôsobili politicko-stranícky škandál. ${ }^{38}$ Deň po ich konaní na sprievodnej slávnosti kladenia základného kameňa novostavby meštianskej školy narušenie osláv odsúdil, 39 čoho dôsledkom bola strata dôvery najvyššieho straníckeho šéfa. Kvôli jeho prejavu na oslavách a článku uverejnenom v Slovenskom učitel'ovi, v ktorých hovoril o „zdravých a triezvych kruhoch v strane“, mu Andrej Hlinka 17. augusta 1933 adresoval list s vyčítavým obsahom, v ktorom ho obvinil z porušenia straníckej disciplíny. Rovnako si Mojto vyslúžil kritiku aj za prijatie sokolskej delegácie z Čiech. Hlinkovi prekážali aj jeho intenzívne styky s ministrom Ivanom Dérerom z vládnej ČSSD. 40 Vzájomný konflikt s vedením vlastnej strany vyvrcholil v roku 1935, ked' sa pred parlamentnými vol'bami predseda HSL'S postavil proti nominácii Mojta na volebnú kandidátku, a hoci mu zo straníckeho generálneho sekretariátu prehlásenie o prijatí kandidatúry napokon zaslali, Mojto sa ju rozhodol neprijat'. ${ }^{41}$

František Mojto sa po tomto incidente a nových skúsenostiach z vrcholovej politiky rozhodol venovat' predovšetkým oblastiam súvisiacim s výkonom funkcie starostu a správou zoborskej školy, zamestnávala ho aj pedagogická spisba a redigovanie periodika Slovenský učitel', pričom sa už ale nemusel viazat' prísnou disciplínou parlamentného klubu HSL'S. Predmetom jeho článkov boli zväčša historické udalosti, jazykovedné polemiky, školská problematika, krest’anská náuka a pod. Mesto bolo $\mathrm{v}$ tomto čase $\mathrm{z}$ jeho iniciatívy spoluorganizátorom historickej výstavy

\footnotetext{
${ }^{37}$ Pamätná kniha mesta Nitry II., s. 50.

${ }^{38}$ Bližšie pozri: ARPÁŠ, Robert: Prvky cyrilo-metodskej tradície ako súčast' Pribinovho odkazu? (Oslavy 1100. výročia krest'anstva v Československu). In: Konštantínove listy, 2017, roč. 10 , č. 1 , s. 233-240.

${ }^{39}$ Lidové noviny, 15. 8. 1933. Po skončení slávností už 18. augusta 1933 obecné zastupitel'stvo vyjadrilo nesúhlas s počínaním hlinkovcov a ospravedlnilo sa vláde. ŠA NR, f. Mestský úrad v Nitre, č. 24/1933, zápisnice zastupitel’stva.

40 SNA, f. NS, šk. 3, TnLuud 4/45-52.

${ }^{41}$ SNA, f. NS, šk. 3, TnL'ud 4/45-6.
} 


\section{Martin Hetényi}

v Uhorskom Hradišti. ${ }^{42}$ Jednou z jeho priorít sa stala reorganizácia a modernizácia dopravy, ciest, uličnej siete a bývania v duchu implementácie vtedajších urbanistických procesov reprezentujúcich intencie moderného mesta. ${ }^{43}$ Nitra sa vd'aka nebývalému stavebnému rozmachu teritoriálne rozšírila už v rokoch 1919 - 1930. V prvom desat'ročí republiky sa zhustili sídelné jednotky, postavili účelové verejnoprospešné stavby a reprezentatívne budovy, vybudovali sa nové predmestia a pril'ahlé obce nadobudli mestský ráz. Po roku 1930, teda v čase vel'kej hospodárskej krízy, stavebný ruch na určitú dobu poklesol. Po nástupe Mojta do starostovskej stoličky sa postupne situácia znovu začala konsolidovat'. Na čele samosprávy riadil pomerne široký záber rozvojovej výstavby - pokračovala regulácia rieky Nitra, stavali sa nové školy (meštianska škola na terajšej Ulici Fr. Mojtu aj škola pri kláštore), Robotnícky kultúrny dom, napredovalo sa i v nahrádzaní plynových pouličných svietidiel elektrickým osvetlením. Napriek pozitívam pestré zloženie mestskej samosprávy viedlo neraz $\mathrm{k}$ názorovej konfrontácii a analýza miestnej tlače z medzivojnového obdobia takisto dokumentuje nespokojnost' časti občanov s činnost'ou nitrianskej samosprávy a úradníkov obecného úradu. ${ }^{44}$ Je možné predpokladat', že Mojto vedel situačne využívat' nejednotnost' mestského parlamentu na pragmatické presadzovanie svojich zámerov.

Posledné demokratické vol'by do obecných zastupitel'stiev v medzivojnovej republike sa uskutočnili 22. mája 1938. Narastajúce vnútropolitické napätie v Československu od jari 1938 vyvolané anšlusom Rakúska a následná lavína udalostí na domácej scéne - požiadavky HSL'S na dosiahnutie autonómie Slovenska či nemeckých a mad'arských politických činitel’ov na územnú revíziu štátnych hraníc, ${ }^{45}$ sa nevyhnutne museli odzrkadlit' v predvolebnej atmosfére i v samotných volebných výsledkoch. Konfrontačná predvolebná kampaň privodila nebývalú polarizáciu verejnosti s vysokou volebnou účast'ou aj v Nitre. Z 11592 oprávnených voličov odovzdalo najviac hlasov Zjednotenej krajinskej krest'ansko-socialistickej a mad'arskej národnej strane (ZMS), d'alej HSL'S a sociálnom demokratom. Po vol'bách pokračovalo v práci mestského zastupitel'stva 16 pôvodných poslancov, takže pri jeho fungovaní bola zaručená určitá kontinuita. Opätovne prevládala stredná vrstva, pričom v nej

\footnotetext{
${ }^{42}$ SNA, f. NS, šk. 3, TnL’ud 4/45-6.

${ }^{43}$ Bližšie pozri: MORAVČÍKOVÁ, Henrieta: Zrod moderného mesta: zmeny obrazu slovenských miest v druhej polovici 19. a prvej polovici 20. storočia. In: Forum Historiae, 2016, roč. 10, č. 2, s. 1-11. Dostupné na internete: http://www.forumhistoriae.sk/sites/default/ files/01-moravcikova-zrod-moderneho-mesta-zmeny-obrazu-slovenskych-miest1.pdf. 44 ZUBÁCKA, I.: Nitra, s. 35 a 46.

${ }^{45}$ Bližšie pozri napr. ARPÁŠ, Róbert: Autonómia : vít'azstvo alebo prehra? : Vyvrcholenie politického zápasu HSL'S o autonómiu Slovenska. Bratislava : Veda, 2011. 200 s. LETZ, Róbert: Slovenská l'udová strana v dejinách 1905 - 1945. Martin : Matica slovenská, 2006. 720 s.
} 
klesol počet vysokoškolsky vzdelaných poslancov z 8 na 5 . Rovnako klesol aj počet zástupcov robotníctva. ${ }^{46}$

Výsledky v Nitre priniesli po rozložení politických síl výnimočnú patovú situáciu. V novom nitrianskom mestskom zastupitel'stve získala Zjednotená mad'arská strana 11 mandátov, HSL'S (do zastupitel'stva sa na jej kandidátke dostal aj oblastný velitel' Hlinkovej gardy a šéfredaktor Nitrianskej stráže Vojtech Višňovský) a sociálni demokrati po 9 mandátov, národní socialisti 4, KSČ 3, zvyšok obsadili ostatné strany. Vytvorili sa dva tábory s približne rovnakým počtom zástupcov v mestskej rade a zastupitel'stve. Na jednej strane stálo široké zoskupenie bývalých centralistických strán - sociálnych demokratov, spojených židovských strán, agrárnikov a československých lidovcov, ktoré sa do boja o pozíciu starostu rozhodlo nominovat' Františka Kopečka (ČSSD). Na druhej strane sa ocitla dvojkoalícia Zjednotenej mad'arskej strany a HSL'S, t. j. strán, ktoré na nitrianskej radnici pod vedením Mojta už v predchádzajúcom období spolupracovali. Po niekol'kých opakovaných vol'bách mestského zastupitel'stva, ked' obaja kandidáti získali rovnaký počet hlasov (21), muselo rozhodnút žrebovanie. Žreb napokon prial Františkovi Mojtovi a jeho koalícii, ku ktorej sa pridali aj lidovci. Opozičné zoskupenie nezískalo ani jeden z postov vo vedení Nitry a nová koalícia obsadila aj miesta zástupcov starostu advokátom Dr. Bernardom Rolfeszom (predseda miestnej organizácie Zjednotenej mad'arskej strany) a Dr. Alexandrom Arnoldom (Československá strana lidová, nebol členom poslaneckého zboru). ${ }^{47} \mathrm{Aj}$ $\mathrm{z}$ tohto dôvodu zástupcovia neúspešného tábora $\mathrm{v}$ mestskej rade vol'by niekol'kokrát napadli. Výsledky však zostali v platnosti. Neúspešné napadnutie volieb zástupcami neúspešného tábora bolo v prol'udáckej miestnej tlači detailne rozoberané. Tieto články podnecovali v meste nielen politické, ale aj náboženské rozbroje a antisemitské výpady. ${ }^{48}$

Rok 1938 vrcholil mníchovskou krízou a Viedenskou arbitrážou. Výkonný výbor HSL'S v Žiline s reprezentantmi d’alších slovenských strán prijal dňa 6. októbra 1938 Žilinskú dohodu o autonómii Slovenska. Prijatie Viedenskej arbitráže z 2. novembra 1938, ktorá rozhodla o odstúpení južných oblastí Mad'arsku, Mojto - ako napokon väčšina spoločnosti na Slovensku - vnímal ako krivdu. ${ }^{49}$

Totalitarizačné procesy sa vo verejnom živote začali prejavovat' v rôznych formách viac-menej okamžite. Už prvé kroky autonómnej vlá-

\footnotetext{
46 Pamätná kniha mesta Nitry II., s. 89.

47 ŠA NR, f. Mestský úrad v Nitre, č. 34/1933, zápisnice zastupitel’stva.

48 PALÁRIK, Miroslav - MIKULÁŠOVÁ, Alena: Prelomový rok 1938. In: PALÁRIK, Miroslav MIKULÁŠOVÁ, Alena - HETÉNYI, Martin: Nitra v rokoch 1939 - 1945 (Dejiny Nitry v školskej praxi). Doplnkový učebný text pre základné a stredné školy. Nitra : UKF v Nitre, 2020, s. 8. ${ }^{49}$ SNA, f. NS, šk. 3, TnL'ud 4/45-6.
} 


\section{Martin Hetényi}

dy bezprostredne po 6. októbri 1938 poukazovali na snahu urýchlene zverit' moc do rúk lojálnych členov alebo sympatizantov HSL'S prijatím viacerých opatrení smerujúcich k úpravám v oblasti samosprávy. Zmeny na vnútropolitickej scéne, ktoré v októbri 1938 vyústili do zákazu l'avicových a židovských politických strán, resp. zlúčenia ostatných predmníchovských strán s HSL'S, sa rýchlo odrazili aj na regionálnej a lokálnej úrovni. Podobne ako v celej krajine, proces likvidácie volenej samosprávy na Slovensku prebiehal vo viacerých fázach už na konci roku $1938^{50}$ a HSL'S si začala uzurpovat' pozície vládnych komisárov, resp. členov poradných zborov už na konci roku 1938. Prijaté opatrenia viedli k odstráneniu predstavitel'ov politickej opozície zo samospráv, prípadne k likvidácii demokraticky volenej samosprávy ${ }^{51}$ a do čela obcí boli podl'a §28 zákona č. 243/1922 Sb. z. a n. menovaní lojálni vládni komisári. Šlo tak o zneužitie krajného zákonného prostriedku nerešpektujúc jeho pôvodný charakter ako dočasného opatrenia pri správe mestských záležitostí. ${ }^{52}$

Jedným z prvých realizovaných opatrení nastupujúcej politickej garnitúry boli mocenské zásahy v obecných zastupitel'stvách v takých sídlach, v ktorých HSL'S nemala prevahu. Ako už bolo spomenuté, hoci na čele mesta stál predstavitel' HSL'S, Nitru nemožno označit' za typickú baštu l'udákov. Napriek tomu, resp. vd'aka Mojtovmu postaveniu v meste neprišlo k takým dramatickým presunom moci ako v iných slovenských mestách a obciach a obecné zastupitel'stvo tu zostalo ešte pomerne dlhý čas zachované. Z celoštátneho hl'adiska šlo o výnimočnú pozíciu Nitry, napríklad v susednom regionálnom centre v Zlatých Moravciach, kde HSL'S získala v posledných obecných vol'bách z 20 poslaneckých miest len šest' mandátov, rozpustil Krajinský úrad miestne zastupitel'stvo už 17. novembra 1938. 53

Okresný úrad v Nitre 23. januára 1939 rozhodol o pozbavení členstva v nitrianskom mestskom zastupitel'stve 14 poslancov zaniknutých politických strán (KSČ, ČSSD, židovské strany) a kooptovaní nových členov podl'a návrhu HSL'S. ${ }^{54} \mathrm{~V}$ praxi šlo o proces doplnenie jednotlivcov s požadovanými schopnost'ami v duchu predstáv vládnucej politickej strany. Zástupcovia l'udákov tak v mestskom zastupitel'stve a obecnej rade získali dominantné postavenie. Do okruhu vedenia mesta sa dostali členovia štátostrany, ktorá u nitrianskeho voličstva nemala v predchádzajúcom období významnejšie zastúpenie. V zastupitel'stve zostali tiež členovia

\footnotetext{
${ }^{50} \mathrm{~K}$ fázam likvidácie obecnej samosprávy bližšie pozri: PODOLEC, O.: Postavenie obecnej samosprávy, s. 647-668.

${ }^{51}$ NIŽŇANSKÝ, E.: Zmocnenie, s. 14-44.

52 PEKÁR M. - TOKÁROVÁ, Z.: Výmeny mestských politických elít, s. 148.

53 ŠA NR, f. OÚ Zlaté Moravce, šk. 1, Zápisnica z Ústrednej volebnej komisie.

${ }^{54}$ Pamätná kniha mesta Nitry II., s. 91.
} 
Zjednotenej mad'arskej strany, ktorých predstavitel' Bernard Rolfesz bol aj zástupcom starostu. Štvrtinový podiel v mestskom parlamente zaručoval relatívnu spokojnost' predstavitel'ov mad'arskej menšiny. ${ }^{55}$

Prestíž Nitry sa zákonite zvýšila po Viedenskej arbitráži a následnej územnej strate iného symbolického miesta - Devína v prospech Tretej ríše z jesene 1938, čo sa prirodzene prejavilo v zvýšenej miere pozornosti zo strany l'udáckej politickej garnitúry. Snaha o získanie kontroly nad vedením mesta bola očividná v radikálnych kruhoch HSL'S a Hlinkovej gardy. Obhájenie obecného zastupitel'stva v Nitre si možno vysvetlit' najmä silnou pozíciou starostu Františka Mojta, predíženej ruky konzervatívnej frakcie HSL'S. Mojto sa zasadzoval proti rozpusteniu voleného obecného zastupitel'stva okrem iného aj u predsedu autonómnej vlády Jozefa Tisa. Za Mojtom, na výmene ktorého mali záujem aj predstavitelia l'udáckych radikálov Vojtech Tuka a Alexander Mach, stáli okrem Tisa vysokí cirkevní hodnostári. ${ }^{56} \mathrm{Z}$ týchto dôvodov na jeho odvolanie či totálne odstavenie z politiky nikdy rad neprišiel, a to ani v neskorších štádiách l'udáckeho politického režimu. V Nitre sa v rámci prvej fázy procesu likvidácie volenej samosprávy príliš neuplatnil ani národný výbor na rozdiel od iných obcí a miest, kde si toto alternatívne l'udácke mocenské centrum uzurpovalo kompetencie samosprávnych orgánov. ${ }^{57}$ Slovenský národný výbor vznikol v Nitre 10. októbra. Do vedenia bol zvolený predseda okresnej organizácie HSL'S a kanonik Dr. Jozef Buday, ktorý v tom čase pôsobil ako podpredseda Senátu Národného zhromaždenia HSL'S (bol dlhoročnou šedou eminenciou strany až do jeho skonu v novembri 1939). Podpredsedami sa stali František Mojto, Peter Rovnianek (prednosta stanice) a Dr. Štefan Klučovský (právnik a redaktor miestnych novín). Výbor mal celkovo 25 členov a podiel'al sa na organizovaní verejných manifestácií, ktoré často nadobúdali protičeský charakter. ${ }^{58}$ Nitriansky výbor sa však nestal svojou činnost'ou zásadnou mocenskou alternatívou k zvolenému vedeniu mesta. Výbory boli rozpustené 19. decembra 1938.59

V nasledujúcich častiach rozboru je pozornost' venovaná otázkam, akú úlohu hral na politickej scéne mesta Mojto v d'alšom období a v čom spočívalo ideologické založenie politicky „vyhovujúceho“ miestneho lídra. Mesto ako jeden z prvých dopadov viedenského verdiktu, po ktorom sa

\footnotetext{
55 NAGY, Z. - SLNEKOVÁ, V.: Nitra v období totality, s. 327.

56 SNA, f. NS, šk. 3, TnLuud 4/45-26.

57 PODOLEC, O.: Postavenie obecnej samosprávy, s. 647-668. Jedným z mála návrhov výboru bolo premenovanie niektorých ulíc. Pamätná kniha mesta Nitry II., s. 90.

${ }^{58}$ Národný výbor v Nitre. In: Svornost', 1938, roč. 2, č. 42, s. 4. Pozri tiež: IZÁK-HVIEZDIN, Ján: Črty z pohnutých časov v Nitre 1938 - 1939. Nitra : Prvá slovenská kníhtlačiarna, 1940. ${ }^{59}$ Bližšie pozri: FIAMOVÁ, Martina: Formovanie a činnost' ústredných orgánov štátnej správy na autonómnom Slovensku (október 1938 - marec 1939). Bratislava : Veda, 2020. 264 s.
} 


\section{Martin Hetényi}

dostalo do bezprostredného susedstva s Mad'arskom, pocítilo imigráciu väčšieho množstva prist'ahovalcov. Už po príchode prvých rodín utečencov na Slovensko ${ }^{60}$, slovenská vláda poverila Slovenskú ligu, aby zrealizovala úspešnú zbierku v prospech vyst'ahovalcov $\mathrm{z}$ arbitrážneho územia. ${ }^{61}$ Nitrianske mlyny, v ktorých ako člen správnej rady pôsobil aj Mojto, darovali na akciu 2 vagóny múky. Samotné mesto ako právnická osoba poskytlo na pomoc pre utečencov 5 tisíc korún. ${ }^{62} \mathrm{~V}$ Nitre sa už od novembra 1938 kopili protižidovské a protičeské nápisy, čo Mojto verejne odsudzoval. Stáli za nimi príslušníci Hlinkovej gardy. ${ }^{63}$ Vo svojom okruhu bol známy vyhraneným postojom k l'udáckym radikálom. So založením Hlinkovej gardy nikdy nesúhlasil a mal k nej aj neskôr odmietavý prístup. Podl'a jeho vyjadrení mu prekážala skutočnost', že okrem regulárnej armády pôsobil v štáte aj iný ozbrojený zbor, ktorý mal podiel na štátnej moci. Nesúhlasil ani s metódami práce gardistov. Jeho neskrývaná kritika zaiste stála neskôr za tým, že po vypuknutí Slovenského národného povstania gardisti udali Františka Mojta Gestapu, čím sa snažili dosiahnut' jeho väzobné zaistenie. ${ }^{64}$ Mojta rozhorčili aj verejné vyjadrenia vtedajšieho šéfa Úradu propagandy Alexandra Macha na propagandisticky preceňovanej manifestácii v Rišňovciach z 12. februára 1939, ktorý tu pamätným výrokom zhrnul ciele politického programu časti

\footnotetext{
${ }^{60} \mathrm{~V}$ niekol'kých prípadoch evakuovali členovia jednej rodiny postupne, t. j. najprv otec a až po určitom čase zvyšok rodiny. Šlo, až na malé výnimky, o slovenské rodiny.

61 Výzva slovenskej vlády: „Občania, do radostného vzrušenia, vyvolaného vít'azstvom Slovenskej národnej myšlienky...,miešajú sa aj hlasy hlbokej bolesti. Hranice Slovenska nám pozmenili proti našej vôli a od živého tela národného odtrhli nám státisíce naších rodných bratov slovenských. Ale ani to nie je dost'! Denne nám prichodia na Slovensko naši slovenskí bratia, ktorí opustit' museli Mad'armi obsadené a odtrhnuté územie a vypudení nezachránili si iné než holý život, zanechajúc svoje právom a tvrdou prácou nadobudnuté imanie movité a nemovité....prichádzajú na Slovensko v stave zúboženom bez akýchkolvek hmotných prostriedkov vyčerpaní duševne i telesne. Sú medzi nimi rol'níci, úradníci, študenti, ba i remeselníci a robotníci. Samozrejmé je, že slovenský národ...musí týchto svojich bratov utečencov privinút' $k$ sebe, zaistit' im kus strechy, chleba a odevu...Celá sbierka sa bude prevádzat' pod dozorom povereníkov Slovenskej vlády. Nech niet Slováka, spolku, ústavu, obce, mesta a okresu, ktorý by neprispel k zmierneniu biedy našich bratov-utečencov!..." ŠA NR, f. Okresný úrad v Nitre (OÚ NR), šk. 354, 23779/38 adm.

62 Podobná zbierka Slovenskej ligy na slovenské menšinové školy (školy v obciach na Slovensku, kde Slováci tvorili menšinu) konaná už v októbri 1938 sa skončila neúspechom najmä preto, že nebola pod patronátom štátnej správy. V Nitre bol výsledok nulový - podl'a odpovede starostu z 8. novembra 1938: „....obecenstvo v terajšej dobe nevd'ačne pozerá na takúto akciu a preto výsledok by bol slabý a privodil by viac zla než osohu..." ŠAP NR, f. OÚ NR, šk. 353, 20 122/38 adm.

${ }^{63}$ SNA, f. NS, šk. 3, TnL’ud 4/45-52. Protižidovské heslá sa objavili napríklad v noci z 25. na 26. novembra 1938 na židovských obchodoch. Mestská polícia vyšetrila, že ich autormi boli členovia Hlinkovej gardy, ale nemohla proti nim zasiahnut'. ŠA NR, f. OÚ NR, 2661/1938 prez.

${ }^{64}$ SNA, f. NS, šk. 3, TnL'ud 4/45-6.
} 
HSL'S: „... Mat' svoj štát znamená život, nemat'svoj štát znamená smrt'slovenského národa..." "65 Ani z rozpadu ČSR a vzniku samostatného štátu 14. marca $1939^{66}$ nebol mimoriadne nadšený, čo v kruhu rodiny a známych $\mathrm{v}$ tento deň patrične okomentoval. $\mathrm{V}$ marcových dňoch sa mu zhodou okolností v Prahe vydávala dcéra Gabriela za Čecha Bohumila Plachetku. ${ }^{67}$ Neskôr sa Gabriela aktívne zapojila do ilegálneho hnutia, pomáhala odbojárom v prechode hraníc do Pol'ska, okrem iného pomohla synovi Ivana Dérera s vybavením cestovných víz k prechodu cez pol'ské hranice do Vel'kej Británie. ${ }^{6}$

Mojto sa neskôr obhajoval, že ho nemožno považovat' ani za germanofila. Bol rezervovaný k politickému nátlaku Berlína ${ }^{69}$ a v súkromných kruhoch pokladal za osožnejšie, aby sa Tiso radšej vzdal funkcie prezidenta, ako by mal niest' zodpovednost' za naoktrojovaný politický diktát Nemcov. Po vyhlásení slovenského štátu odmietol aj žiadost' vedúceho nemeckej národnej skupiny v Nitre Waltera Kussa, aby dal počas slávnosti Nemcov vyvesit' na Mestský dom nemeckú zástavu. Nemeckým vojakom po začiatku okupácie roku 1944 tiež odoprel zriadenie nevestinca. ${ }^{70}$

Pochopitel'ne, ako čelný zástupca mesta sa Mojto nemohol vyhnút' prejavom určitého akceptovania novej situácie. Totalitné vládnutie prinášalo

\footnotetext{
65 SNA, f. NS, šk. 3, TnL'ud 4/45-6. HRUBOŇ, A.: Alexander Mach, s. 179.

${ }^{66} \mathrm{~K}$ vzniku slovenského štátu bližšie pozri napríklad: BYSTRICKÝ, Valerián: Od autonómie k vzniku Slovenského štátu. Bratislava : Prodama, 2008. 301 s. BYSTRICKÝ, Valerián: Zahraničnopolitické súvislosti vzniku Slovenského štátu 14. marca 1939. Bratislava : Veda, 2014. 464 s. Prínosné sú publikované dokumenty BYSTRICKÝ, Valerián - LETZ, Róbert - PODOLEC, Ondrej (eds.): Vznik Slovenského štátu 1. Bratislava : AEPress, 2007. 340 s. BYSTRICKÝ, Valerián - LETZ, Róbert - PODOLEC, Ondrej (eds.): Vznik Slovenského štátu 2. Bratislava : AEPress, 2008. $360 \mathrm{~s}$.

${ }^{67}$ SNA, f. NS, šk. 3, TnL'ud 4/45-6.

${ }^{68}$ SNA, f. NS, šk. 3, TnL’ud 4/45-52. Ivan Dérer sa k tomuto obdobiu vrátil vo svojich povojnových memoároch. DÉRER, Ivan: Slovenský vývoj a lud'ácká zrada. Fakta, vzpomínky a úvahy. Praha : Kvasnička a Hampl, 1946, 367 s.

${ }^{69}$ K slovensko-nemeckým vzt'ahom bližšie pozri napríklad: SCHVARC, Michal: Sicherheitsdienst a Slovensko v rokoch 1938 - 1944 : Od autonómie po Povstanie. Slovenský śtát vo vybraných správach SD od jesene 1943 do septembra 1944. Bratislava: Slovenské národné múzeum - Múzeum karpatských Nemcov, 2006. 460 s. SCHVARC, Michal: Vývoj a zmeny organizačnej štruktúry Deutsche Partei 1938 - 1945. In: Historický časopis, 2006, roč. 54, č. 3, s. 471-502. SCHVARC, Michal - HOLÁK, Martin - SCHRIFFL, David: „Tretia ríša“ a vznik Slovenského štátu : Dokumenty = Das "Dritte Reich" und die Entstehung des Slowakischen Staates. I. Bratislava : Ústav pamäti národa : SNM-Múzeum kultúry Karpatských Nemcov, 2008. 633 s. SCHVARC, Michal - SCHRIFFL, David: „Tretia ríša“ a vznik Slovenského štátu : Dokumenty = Das "Dritte Reich" und die Entstehung des Slowakischen Staates. Dokumente II. Bratislava : Ústav pamäti národa : Historický ústav SAV : SNM-Múzeum kultúry Karpatských Nemcov, 2010. 561 s. NIŽŇANSKÝ, Eduard - TULKISOVÁ, Jana a kol.: Slovensko-nemecké vzt'ahy 1938 - 1941 v dokumentoch I. : Od Mníchova $k$ vojne proti ZSSR = Slowakisch Deutschen Beziehungen 1938 - 1941 in Dokumenten I. Prešov : Universum, 2009. $1171 \mathrm{~s}$. 70 SNA, f. NS, šk. 3, TnL'ud 4/45-6.
} 
mnohé konkrétne dopady na spoločenský a kultúrny život spoločnosti. Vládnucou stranou a jej činorodost'ou bol dôsledne obsadený celý verejný priestor. Nedlho po vyhlásení autonómie Slovenska štátny aparát začal vyvíjat' tlak na zmeny v názvoch ulíc a verejných priestranstiev. V Nitre sa nevyhovujúce názvy týkali desiatich ulíc, jedného námestia a cesty. Išlo o ulice pomenované po osobnostiach spätých s dejinami Nitry, ale nevyhovujúcich novým ideologickým pomerom. Prvý návrh na zmenu názvov niektorých ulíc a námestí po vzniku samostatného slovenského štátu podal starostovi Nitry Františkovi Mojtovi člen mestskej rady Karol Sevcsík už 20. marca 1939. Premenované boli aj názvy spojené so sv. Štefanom a sv. Václavom, ktorí boli chápaní ako neslovenskí svätci. Vládny komisár mesta potom rozhodnutím z 2. mája 1941 zmenil ich názvy opierajúc sa o zoznam Matice slovenskej a osobné návrhy župana, pričom preferované boli označenia odkazujúce na vel'komoravskú tradíciu, prípadne na osobnosti spojené s HSL'S. Je paradoxné, že bola v tomto období premenovaná aj ulica, ktorá niesla meno Mojtovho predchodcu $\mathrm{z}$ čias ČSR Karola Coboriho. ${ }^{71}$ Ako sa ukáže d'alej, del'ba moci na lokálnej úrovni, resp. jej centralizácia sa plnohodnotne prejavila aj v tejto oblasti. Komisia pre pomenovávanie ulíc sa poslednýkrát zišla v polovici roku 1940 , v d'alšom období prebral jej právomoci vládny komisár mesta. ${ }^{72}$

Ked' sa 26. októbra 1939 v Bratislave konala vol'ba prezidenta Slovenskej republiky, po celej krajine prebehli slávnostné akcie. Výnimkou nebola ani Nitra - večer napochodovali gardisti pred Mestský dom, z balkóna ktorého slávnostne prehovoril starosta. ${ }^{73}$ Ked'že Mojto nebol ani poslancom slovenského snemu a aj jeho politické angažovanie sa sústredilo predovšetkým na problémy obyvatel'ov mesta, jeho prejavy boli $\mathrm{v}$ tomto období v tlači publikované len sporadicky. Publikoval predovšetkým v Slovenskom učitel'ovi, no napäté vzt'ahy s gardistami mu nebránili publikovat’ aj články v regionálnom gardistickom týždenníku Nitrianska stráž, v ktorých sa nevyhol pochvalným slovám na adresu niektorých l'udáckych činitel'ov či sviatkov. ${ }^{74}$ Ako hlava mesta zvykol vítat' rôzne delegácie - z významnejších podujatí možno spomenút' Dni mládeže v máji 1940 s účast'ou viac ako 20 tisíc mládežníkov, župný zjazd HSL’S, dožinkové slávnosti v auguste 1940, desiate výročie pamätných

\footnotetext{
${ }^{71}$ ŠA NR, f. MeÚN, šk. 116, č. 231.

72 Bližšie pozri: PALÁRIK, Miroslav - MIKULÁŠOVÁ, Alena: Názvy ulíc a námestí v zajatí politiky: zoznam slovenských dejatel'ov schválených na pomenovanie verejných priestranstiev v rokoch 1939 - 1945. In: Studia Historica Nitriensia, roč. 20, č. 1, 2016, s. 178-211. PALÁRIK, Miroslav - Alena MIKULÁŠOVÁ, Alena: Revízia znakov, symbolov, pamätníkov a sôch v období autonómie a Slovenskej republiky 1938 - 1945 : Príklad mesta Nitra. In: Historický časopis, 2018, roč. 66, č. 3, s. 523-546.

73 Pamätná kniha mesta Nitry II., s. 95. NAGY, Z. - SLNEKOVÁ, V: Nitra v období totality, s. 327. ${ }^{74}$ SNA, f. NS, šk. 3, TnĹud 4/45-38.
} 
Pribinových osláv a pod..$^{75}$ Jeho povinnost'ou bolo tiež privítat' vládnych činitel'ov po ich príchode do Nitry pri príležitosti rôznych osláv. ${ }^{76}$ Hoci patril k oponentom Tukovej a Machovej línie, pri návšteve predsedu vlády Vojtecha Tuku a ministra vnútra Alexandra Macha počas dožinkových slávností v Nitre v lete 1940 sa vyjadril: „Po Nitre sa hovorí mnohokrát, že je Pribinova, Svätoplukova, ba aj Tisova a teraz by sme mohli už povedat', ked' je medzi nami p. predseda vlády dr. Tuka a minister Mach, že je aj Tukova a Machova." 77 V septembri 1941 privítal aj ríšskeho ministra vnútra Wilhelma Fricka počas jeho cesty po Slovensku. ${ }^{78}$

Po nariadení vlády z 18. marca 1939 museli byt' zo štátnej služby prepustení zamestnanci českej národnosti. Mojto, známy kladným vzt’ahom k Čechom, za viacerých z nich intervenoval na vyšších miestach (konal tak napokon už za čias vykonávania poslaneckého mandátu) a vymohol aspoň výnimky pre nenahraditel'ných špecialistov. ${ }^{79}$

V neutešenom postavení sa $v$ dôsledku uplatňovania oficiálnej protižidovskej politiky ocitli tiež nitrianski Židia. ${ }^{80}$ Mojto viackrát intervenoval za pokrstených Židov na štátnej polícii, na nitrianskom okresnom úrade i na centrálnych úradoch štátu. Napriek zákazu prijal do l'udovej školy na Zobore deti židovského pôvodu (Pless, Ulrich a i.), intervenoval aj na ministerstve školstva a národnej osvety, aby mohli židovské deti študovat' na iných nitrianskych školách (deti z rodín Dr. Grála, Gregušovcov, Kramerovcov). Zásluhou Mojta, ktorý podpísal obecné prehlásenie $\mathrm{s}$ odporúčaním verejným úradom, mohol v priestoroch radnice mesta nad'alej so svojim pohostinstvom pokračovat' vo svojom podnikaní Žid

\footnotetext{
${ }^{75}$ Bližšie pozri: HETÉNYI, Martin - IVANIČ, Peter. Poznámky k šíreniu kultu sv. Cyrila a Metoda v rokoch 1939 - 1945 na príklade mesta Nitra. In: Život v Slovenskej republike : Slovenská republika 1939 - 1945 očami mladých historikov IX. Bratislava : Ústav pamäti národa, 2010, s. 336-345.

${ }^{76}$ SNA, f. NS, šk. 3, TnLuud 4/45-6.

77 „Po Nitre sa hovorí mnohokrát, že je Pribinova, Svätoplukova, ba aj Tisova a teraz by sme mohli už povedat', ked' je medzi nami p. predseda vlády dr. Tuka a minister Mach, že je aj Tukova a Machova. "SNA, f. NS, šk. 3, TnLuud 4/45-33. Pri vyšetrovaní však bolo NB aj obžalobcom zistené, že Mojto nebol zástancom Tukovej a Machovej línie.

78 SNA, f. NS, šk. 3, OnLuud 7/45-11.

${ }^{79}$ SNA, f. NS, šk. 3, TnL’ud 4/45-7.

${ }^{80} \mathrm{~K}$ realizácii protižidovskej politiky v Nitre bližšie pozri: KÖNÖZSYOVÁ, Lucia: Deportácie Židov z Nitry za autonómie Slovenka 4. - 5. 11. 1938 v dokumentoch. In: Studia Historica Nitriensia VIII., Nitra: UKF, 2000, s. 241-297. KÖNÖZSYOVÁ, Lucia: Možnosti záchrany Židov začiatkom deportácií v roku 1942 - modelové mesto Nitra. In: Studia Historica Nitriensia IX. Nitra : UKF, 2001, s. 89-120. KÖNÖZSYOVÁ, Lucia: Príprava na arizačný proces vo forme nariadení o vládnych dôverníkoch v podnikoch ako prejav hospodárskeho antisemitizmu. Židovská komunita v Nitre. In: Studia Historica Nitriensia XI. Nitra : UKF, 2003, s. 165-182. KÖNÖZSYOVÁ, Lucia: Židovská komunita v Nitre v období autonómie Slovenska. In: Židovská komunita na Slovensku. Obdobie autonómie. Porovnanie s vtedajšími udalost'ami v Rakúsku. Bratislava : ZING PRINT, 2000, s. 49-82.
} 
Vojtech Guttmann, a to až do 14. augusta 1940, kedy mu koncesiu odňal župný úrad. Užupana osobne intervenoval aj pri likvidačnej pokute, ktorú Štátny policajný úrad 14. septembra 1939 vyrubil židovskému vel'koobchodníkovi Bernardovi Diamantovi za predražovanie tovaru. Na mestskom úrade zamestnával do poslednej možnej chvíle Ing. Ferdinanda Felsenburga, ktorý zastával post prednostu stavebno-technického oddelenia mestského úradu až do 27. augusta 1940, kedy ho župný úrad nariadil vymenit' za „Slováka, katolíka a autonomistu“ Štefana Tučného.

Zdokumentovanými boli viaceré prípady jeho konkrétnej pomoci. Ako predseda správnej rady Nitrianskych mlynov pomáhal generálnemu riaditel'ovi Eduardovi Fürstovi a 11 zamestnancom židovského pôvodu, ktorých mali prepustit' zo zamestnania 1. júla 1940, odkladat' ich výpovede. Vybavoval osobitné pracovné povolenia a rôzne výnimky u prezidenta Jozefa Tisa pre rodiny Schwitzerovú, Kramerovú, Resslerovú, pre občanov Dínera, Donátha, Mórica Martina Fischera, riaditel'a židovskej školy v Spišskej Novej Vsi Dávida Körösa či pre nitrianskeho lekára Dr. Ernesta Pressera. Pred rokom 1940 bývalo v mestských obytných domoch 11 židovských rodín a hoci siedmym Židom dalo mesto výpoved' k 1. októbru 1940, štyrom z nich starosta umožnil bývat' v nich i nad'alej. Mojtov vtedajší zástupca Bernard Rolfesz ako advokát následne pomohol v súdnom procese všetkým vypovedaným Židom. ${ }^{81}$ Po nemeckej okupácii koncom roka 1944 vymáhal u Gestapa prepustenie Dr. Vásárhelyiho, rovnako rodiny Starkovcov aj z koncentračného tábora v Seredi. ${ }^{82}$ Bol aj krstným otcom pri krste Židov (bol kmotrom v rodine Emanuela Resslera, Emila Kramera, dr. Huga Vásárhelyiho), rovnako aj jeho syn, za čo si vyslúžili karikovanie v l'udáckej tlači (Kocúr a Gardista) a táto skutočnost' neostala bez patričnej pozornosti miestnych gardistov. ${ }^{83}$

Mojto sa dokonca nevyhol udaniu na najvyššie politické miesta, ked' bola prostredníctvom prednostu Ústredne štátnej bezpečnosti ministrovi Machovi zaslaná podrobná správa osobného tajomníka župana a miestneho velitel'a Hlinkovej mládeže Jozefa Pillaya z 5. septembra 1940 s hodnotením konkrétnych krokov Mojta, ktorými pomáhal a chránil židovských obyvatel'ov. ${ }^{84}$ Tento viacstranový udavačský záznam bol spísaný zrejme na základe podnetu vtedajšieho nitrianskeho župana Andreja Dudáša. ${ }^{85} \mathrm{~V}$ novembri 1941 sa Mojto v úlohe vládneho komisára zúčastnil na poradách u ministra vnútra Macha, na ktorých sa riešila židovská otázka. Na poradu dostal spolu s ostatnými miestnymi funkcionármi

\footnotetext{
${ }^{81}$ SNA, f. NS, šk. 3, TnLuud 4/45-26.

82 SNA, f. NS, šk. 3, TnL'ud 4/45-52.

83 SNA, f. NS, šk. 3, TnL'ud 4/45-6, TnLuud 4/45-7. SNA, f. NS, šk. 3, TnL’ud 4/45-52.

${ }^{84}$ SNA, f. NS, šk. 3, TnL’ud 4/45-11. SNA, f. NS, šk. 3, TnL'ud 4/45-26.

${ }^{85}$ SNA, f. NS, šk. 3, TnL'ud 4/45-26.
} 
pozvanie, ked’že sa rokovalo o presune Židov z Bratislavy okrem iných miest aj do Nitry. Jeho prednesené námietky s týmto presunom súviseli s nedostatočnými ubytovacími kapacitami. ${ }^{86}$ Úrady do Nitry napokon na jeseň 1941 pred plánovanými deportáciami sústredili stovky Židov z iných častí Slovenska, pretože úmysel úradov bolo vytvorit' väčšie geto z nitrianskych Pároviec. 87

K zmene v správe Nitry napokon došlo po salzburských rokovaniach z júla 1940, po ktorých nastalo posilnenie radikálnej pronacistickej frakcie HSL'S vo vláde a štruktúrach HSL'S. Dňa 14. novembra 1940 bola zo zákona rozpustená nitrianska mestská samospráva a rozpustené mestské zastupitel'stvo a mestskú radu nahradil vládny komisár s poradným zborom. ${ }^{88}$ Po nadobudnutí účinnosti zákona č. 190/1939 Sl. z. prešla dozorná pôsobnost' nad obcami z okresných úradov na župné úrady ${ }^{89}$, takže rozpustenie sa udialo rozhodnutím nového župana Štefana Haššíka, ktorý sa od svojho príchodu na nitriansky župný úrad 13. októbra 1940 opakovane st'ažoval na pomery v správe mesta a tento krok podporoval aj generálny sekretariát HSL'S. Štátnu moc popudzovala okrem iného skutočnost', že HSL'S sa delila o čast' postov s Mad'arskou stranou.

Za vládneho komisára Haššík vymenoval dovtedajšieho starostu Františka Mojta, jeho zástupcom sa stal riaditel' miestnej nemocnice Dr. Jozef Závodný. Pôsobenie Závodného, ktorý sa o niekol'ko mesiacov funkcie na vlastnú žiadost' z dôvodu enormného pracovného vyt’aženia vzdal, bolo len epizodické a župan na tento post vymenoval nitrianskeho rímskokatolíckeho farára a šéfredaktora Nitrianskej stráže Michala Bolečka. ${ }^{90}$ Do poradného zboru boli županom na návrh miestnej organizácie HSL'S vybraní nacionálne orientovaní katolíci: predseda Krajského súdu a zároveň predseda miestnej organizácie HSL'S Dr. Ján Rybárik, nitriansky farár Michal Boleček, riaditel' Tatrabanky Anton Valik, klampiar Štefan Jankula, vinohradník Ján Kaňuch, robotník Vincent Boháč, podplukovník vo výslužbe Viliam Gregory zastupujúci nemeckú menšinu a obvodový predseda Mad'arskej strany Dr. Ákos Gyürky. ${ }^{91}$ Povolania členov

\footnotetext{
${ }^{86}$ SNA, f. NS, šk. 3, TnL’ud 4/45-39. SNA, f. NS, šk. 3, TnL’ud 4/45-52.

87 ŠA NR, f. Nitrianska župa III., č. 57/1941 prez. K jeho vybudovaniu nedošlo, pretože väčšina Židov bola nasledujúci rok deportovaná do koncentračných táborov.

88 ŠA NR, f. OÚ NR, šk. 49, č. 217/1941 prez. ŠA NR, f. OÚ NR, šk. 362, č. 3326/1939 prez. ŠA NR, f. OÚ NR, šk. 396, č. 20002/1940 adm. ŠA NR, f. Okresné četnícke velitel'stvo NR, šk. 3 , č. $122 / 1941$ prez.

89 TIŠLIAR, Pavol: Okresné zriadenie na Slovensku v rokoch 1918 - 1945. Krakov : Spolok Slovákov v Pol'sku, 2013, s. 126-127.

90 Pamätná kniha mesta Nitry II., s. 97. In: Nitrianska stráž, roč. 21, č. 11, 21. marec 1941, s. 1. Boleček sa stal správcom farnosti po úmrtí Kolomana Szmidu, člena a miestneho poslanca Zjednotenej mad'arskej strany, 7. júna 1939.

${ }^{91}$ Pamätná kniha mesta Nitry II., s. 97.
} 
zboru reprezentovali duch idey stavovského zriadenia. ${ }^{92}$ Mocenským zásahom štátnej byrokracie a znížením počtu členov vedenia boli do vel'kej miery eliminovaní aj reprezentanti Mad’arskej strany, dovtedajší koaliční partneri v rámci obecnej správy. Naopak, privilegovaná nemecká menšina prvýkrát prerazila do správy mesta aspoň v symbolickej podobe. ${ }^{93} \mathrm{Z}$ politického vedenia mesta sa tak vytratila nielen konfesionálna heterogenita, ale aj dovtedajšie reflektovanie pestrej skladby nitrianskeho voličstva. Pri pohl'ade na kreovanie l’udákmi schválenej oficiálnej reprezentácie mesta je zaujímavé aj jej výrazné zúženie. Takáto redukcia znamenala zásadnú koncentráciu moci v rukách úzkej a viac-menej uzavretej skupiny osôb podobného politického presvedčenia. Modifikoval sa tiež spôsob výkonu moci, pretože mesto viedol jeden vládny komisár a ostatní členovia vedenia mesta mali poradnú funkciu. ${ }^{94}$ Pri komparácii s dovtedajšími orgánmi mesta vyplýva zaujímavá skutočnost', že kontinuitu predstavoval okrem samotného Mojta už len Ákos Gyürky, ktorý bol od roku 1938 poslancom miestneho zastupitel'stva. Miera ich vplyvu bola chabá a výraznejšie sa na pôde radnice prejavila len ku koncu vojny. Živnou pôdou radikálov boli gardistické periodiká a neskôr i nitriansky Župný úrad s agilným Štefanom Haššíkom, do októbra 1940 županom Šarišsko-zemplínskej župy, ktorý si zamenil pozíciu s Andrejom Dudášom. Miestne noviny Nitrianska stráž, ktoré tieto zmeny zachytili na svojich stránkach konštatovali, že si ich vyžiadal „nový duch slovenských pomerov". ${ }^{95} \mathrm{~V}$ riadení mesta sa však Mojto aj nad'alej snažil uplatňovat' demokratické postupy, pričom jeho poradný zbor zasadal pravidelne každý týždeň, rovnako ako predtým mestská rada. Preto ani príliš neprekvapuje, že predseda vlády Tuka ho ako novomenovaného vládneho komisára odmietol prijat’ na audienciu a čakajúc na chodbách Úradu vlády mu nechal odkázat', aby sa obrátil na rezortného ministra. ${ }^{96}$

Obdobie slovenského štátu je okrem iného spravidla považované za éru dynamického rozvoja kultúrnej, umeleckej a osvetovej činnosti, vedy či športových aktivít. Mesto nezabúdalo na podporu svojich kultúrnych, umeleckých, vzdelávacích a výskumných inštitúcií. V roku 1941 začalo v renovovanom Mestskom divadle pôsobit' Slovenské l'udové divadlo s profesionálnym súborom. Bolo to druhé profesionálne

\footnotetext{
${ }^{92}$ Analogicky sa postupovalo napríklad v meste Prešov, kde boli členmi poradného zboru kňaz, robotník, učitel', rol'ník, pekár, obchodník či bankový úradník. PEKÁR, M. - TOKÁROVÁ, Z: Výmeny mestských politických elít, s. 150.

${ }^{93}$ Miera zastúpenia radikálnejších l'udákov, ktorí v predošlej demokratickej komunálnej politike v Nitre neprerazili nie je z archívnych materiálov zatial' jasná, zdá sa však, že v zbore mohli mat' marginálne zastúpenie.

${ }^{94}$ PEKÁR, M. - TOKÁROVÁ, Z.: Výmeny mestských politických elít, s. 150.

${ }^{95}$ Nitrianska stráž, roč. 20 , č. 44, 10 . november 1940 , s. 1.

${ }^{96}$ SNA, f. NS, šk. 3, TnL'ud 4/45-26.
} 
divadlo na Slovensku v tomto období. ${ }^{97}$ Prvým predstavením nitrianskeho divadla bola dráma Antona Prídavka pod názvom Pribina, ktorá sa hrala pri príležitosti dokončenia renovácie divadla 6. septembra 1941 za účasti župana Štefana Haššíka i vládneho komisára Mojta. ${ }^{98}$ Slovenský štát postupne zaznamenával priaznivý hospodársky rast (najmä vd’aka dlhodobo neudržatel'nej vojnovej konjunktúre a na úkor vybraných skupín obyvatel'ov), čo sa odrazilo aj na ekonomike mesta. V roku 1940 už Nitra neevidovala žiadnu nezamestnanost', hoci sa tak dialo aj v dôsledku núteného arizovania židovských podnikov, zaujatia pracovných miest po odsune Čechov do Protektorátu či brigád v Nemecku. Dobré hospodárske výsledky sa odzrkadlili aj v sociálnej sfére, pravidelne sa valorizovali platy s viacerými druhmi príplatkov. Objem nielen štátnych či súkromných, ale aj mestských investícií mal až do roku 1943 vzostupnú tendenciu. Horšie to už bolo s nedostatkom tovaru dennej spotreby. ${ }^{99}$

V roku 1939 si mesto mohlo dovolit' investovat' do viacerých kl'účových stavebných prác, konkrétne 4 milióny korún do výstavby kasární, 165000 korún do prestavby škôl a mestského divadla, 941000 korún do výstavby ciest, 3180000 korún do regulácie rieky Nitra a 3041289 korún do mestského vodovodu a kanalizácie. ${ }^{100}$ Mojto sa so svojim tímom nad'alej sústredil na zlepšenie zdravotno-hygienických pomerov či na oblast' urbanistického vývoja a budovania technickej infraštruktúry mesta. $V$ roku 1941 zlepšená situácia v rozpočte mesta umožnila investovat' 3 milióny do výstavby mestskej kanalizácie, rovnaké sumy aj do pokračovania regulácie rieky a do dláždenia ulíc, 1,4 milióna korún do d'alšej etapy vodovodných prác, pol milióna na zriadenie parku za parným mlynom, 300 tisíc na výstavbu troch verejných toaliet, 2,5 milióna korún do učňovskej školy, pol milióna korún do železničného nadchodu Pod Borinou a 1 milión na verejné kúpalisko. ${ }^{101}$ Mesto v tomto období upravilo i okolie Župného domu, zaviedlo mestský rozhlas, naprojektovalo stavbu hydrocentrály a mnohé d'alšie investičné akcie. Urbanizmus Nitry pod jeho vedením zaznamenal intenzívne a dynamické vývojové premeny. Nitra tak nemala už len nálepku národného symbolu s historickým významom, ale menila sa na dôležité hospodárske a spoločenskokultúrne mestské centrum.

Od roku 1938 bol Mojto nominovaný do viacerých hospodárskych podnikov. Bol menovaný za vládneho komisára v nitrianskych mlynoch

\footnotetext{
${ }^{97}$ PALÁRIK, Miroslav: Divadelníctvo v Nitre v rokoch 1939 - 1945. In: Studia Historica Nitriensia, 2017, roč. 21, č. 2, s. 385.

98 Pamätná kniha mesta Nitry II., s. 103.

${ }^{99}$ NAGY, Z. - SLNEKOVÁ, V.: Nitra v období totality, s. 328-329.

100 ŠA NR, f. OÚ NR, 461/1940 prez.

${ }^{101}$ ŠA NR, f. OÚ NR, 1068/1940 prez.
} 


\section{Martin Hetényi}

(táto funkcia mu neskôr bola modifikovaná na predsedu správnej rady), za člena a neskôr predsedu nitrianskej sladovne a člena správnej rady Považskej továrne na tuky v Novom Meste nad Váhom. Bol tiež členom dozorného výboru nitrianskeho cukrovaru. Vzhl'adom na skutočnost', že od roku 1939 bol predsedom družstevnej octárne (bývalej octárne rodiny Kramerovcov), bol zvolený za predsedu Zväzu slovenských octární v Bratislave. ${ }^{102}$ Jeden zo synov vládneho komisára, František, šiel v otcových stopách a bol taktiež verejne aktívny. Bol správcom najväčšej tlačiarne kníh v meste s názvom Andrej - Kníhkupectvo, papiernictvo, kníhtlačiareň sídliacej v budove Sekretariátu HSL'S. ${ }^{103}$ František Mojto mladší bol zamestnaný aj ako úradník prvej slovenskej tehelne v Nitre. ${ }^{104}$

Mojtove angažovanie sa pomáhalo udržiavat' aj jeho majetkové pomery. Členstvom v správnych radách si v roku 1940 prilepšil o 28570 korún. V úrade mešt’anostu zarobil ročne približne 12 tisíc korún, pričom $\mathrm{k}$ tomuto platu prináležalo ešte 9 tisíc korún na reprezentačné účely. Značnú čast' predstavoval príjem za učitel'ské povolanie (ročne asi 45 až 50 tisíc korún), redigovanie odborného časopisu Slovenský učitel' mu vynášalo mesačný honorár vo výške 500 korún. Jeho celkové príjmy činili okolo 110 tisíc korún ročne. ${ }^{105}$ Členstvo v Štátnej rade i predsedníctvo v miestnej organizácii HSL'S predstavovali čestné funkcie bez nároku na honorár. Treba dodat', že napriek pomerne vysokým príjmom mu neraz nestačili pokryt' jeho výdavky, takže sa v roku 1943 rozhodol zobrat' si pôžičku 12 tisíc korún a v nasledujúcom roku 13500 korún. ${ }^{106}$

Úzka väzba HSL'S na štát sa odzrkadl'ovala v nitrianskom regióne predovšetkým prelínaním straníckych pozícií s postami vo verejnej a štátnej správe. Mojto zastával po reorganizácii strany od roku 1943 post predsedu miestnej organizácie HSL'S na Zobore. Ako straník však nebol vel'mi aktívny, čo dokazuje aj skutočnost', že ani raz nezvolal členskú schôdzu. Jeho osobná prestíž sa zvýšila po tom, čo bol 24. augusta 1943 na návrh prezidenta menovaný do Štátnej rady až do 1 . februára 1945, ked’ sa zriekol členstva. Tento štátny orgán mal $\mathrm{v}$ danom čase okrem politického

\footnotetext{
102 SNA, f. NS, šk. 3, TnL’ud 4/45-1.

103 ŠA NR, f. Mestský úrad v Nitre, 1942, šk. 119. Zoznam kníhtlačiarov v Nitre k 1. januáru 1942. Predznamenávalo to jeho napojenie na vládnucu stranu. Pobočka tohto celoslovenského podniku vznikla v Nitre v roku 1941. Kníhtlačiareň vznikla spojením troch arizovaných podnikov, a to konkrétne firiem židovských majitel'ov s názvom: bratia Löwyovci, Prvá slovenská kníhtlačiareň v Nitre, podniku Izraela Grossmanna a spol. (Hermes) a firmy Samuela Kleina. Mala 6 zamestnancov. PALÁRIK, Miroslav - MIKULÁŠOVÁ, Alena: Libri prohibiti: zásahy politiky do knižnej produkcie a knižničných fondov počas druhej svetovej vojny na príklade mesta Nitra. In: Muzeológia a kultúrne dedičstvo, 2016, roč. 4, č. 2, s. 127. 104 SNA, f. NS, šk. 3, TnL'ud 4/45-52.
}

105 SNA, f. NS, šk. 3, TnL’ud 4/45-6.

106 SNA, f. NS, šk. 3, TnL'ud 4/45-1. 
súdnictva len obmedzené kompetencie ${ }^{107}$ a zasadol iba dvakrát - 16. októbra a 22. novembra 1944. Na zasadnutiach rada zbavila poslaneckého mandátu Ferdinanda Čatloša a Imricha Zat'ka. ${ }^{108}$

Na konci roku 1943 došlo k d’alšej zmene v obecnej samospráve v rámci poslednej fázy odstránenia pozostatkov prvorepublikovej samosprávy prijatím zákona č. 171/1943 Sl. z., ktorý vstúpil do platnosti 1 . januára 1944. Právne zmeny v obecnej samospráve boli rozvedené vo výnose ministerstva vnútra z 26. januára 1944 pod č. 326-21/1-2/44. ${ }^{109}$ Podl'a tejto legislatívy sa uskutočnili vol'by obecných a mestských výborov, pričom ich praktická realizácia jednoznačne potvrdzovala využitie typologických atribútov nedemokratických režimov. Namiesto vládnych komisárov a poradných zborov nastúpili mešt'anostovia, resp. starostovia s obecnými výbormi. Členov výboru a starostov menoval v pomere určenom zákonom okresný náčelník na návrh politických strán. Kandidátky za HSL'S navrhovala okresná organizácia HSL'S, obdobne postupovali štruktúry menšinových strán. Následne došlo k vol'bám, pričom volit' mohli len členovia spomenutých strán. V praxi sa oklieštenie volebného práva na členov povolených strán - v Nitre len na členov HSL'S prejavilo v zanedbatel'nej volebnej účasti. Vo fáze úpadku režimu sa do čela mesta pokúsili infiltrovat' aj radikáli a Hlinkova garda postavila do neštandardných volieb vlastného kandidáta Ferdinanda Bišču. ${ }^{110}$ Mojto však zostal na čele mesta aj po týchto zmenách, kedy bol zvolený a 27. apríla 1944 županom vymenovaný za nitrianskeho mešt’anostu, no jeho zástupcom sa stal radikál Vincent Hrevsík, penzionovaný železničiar. Druhým zástupcom bol menovaný majitel' pekárne Karol Novák, do mestského výboru sa dostali aj murár Pavol Hudec a statkári Dr. Vojtech Skyčák a Jozef Rečka. ${ }^{111}$

Napriek tomu, že umiernenejšie krídlo HSL’S okolo prezidenta Tisa po prijatí zákona č. 215/1942 Sl. Z. o HSL'S, ktorým sa posilnil autoritatívny

\footnotetext{
107 Šlo o ústredný orgán, ktorý sa skladal zo zástupcov HSL’S, menšinových strán, štátnej správy, územnej samosprávy a záujmových organizácií. Hoci boli formálne právomoci Štátnej rady pomerne silné, $v$ skutočnosti mnoho z nich nenadobudlo význam. Mala sa vyjadrovat' k výkonu súdnej právomoci nad prezidentom a ministrami, zostavovaním kandidátok pre vol'bu do snemu, k niektorým politickým, hospodárskym a kultúrnym otázkam a rozhodovat' o strate mandátu. V roku 1943 bola reorganizovaná tak, že jej počet klesol na 12, pričom 10 menoval prezident, zostávajúce dve miesta nominovali predseda vlády a snemu. Súčasne sa zmenšila i jej kompetencie. Bližšie pozri: PODOLEC, Ondrej. Retribučné procesy s členmi Štátnej rady. In: Pamät' národa, 2015, roč. 11, č. 4, s. 3-23. 108 SNA, f. NS, šk. 3, TnL’ud 4/45-6.

109 ŠAP NR, f. OÚ NR, šk. 531, 7/470/44 adm.

110 SNA, f. NS, šk. 3, TnL’ud 4/45-6.

111 Náhradnými členmi výboru boli obchodník Július Meňhardt, poštár Vojtech Spál, spolkový tajomník OSU Pavol Takáč, profesor Dr. Ondrej Mikloško a riaditel' Hospodárskych škôl Martin Kontka. Pamätná kniha mesta Nitry II., s. 117.
} 
vodcovský spôsob riadenia štátostrany, vplyv a výbojnost' radikálov v Nitre narastali. Na jeseň 1944 prišlo počas zasadnutia mestského výboru k iniciatíve, ktorá Mojta zaskočila. Vnútorná názorová polarizácia miestnej HSL'S vrcholila, ked' jeho zástupca Vincent Hrevsík inicioval odňatie čestného občianstva Nitry československému prezidentovi Edvardovi Benešovi. Mojto so zaradením bodu do programu nesúhlasil a nanúteného hlasovania sa napokon zdržal.112 Hrevsíkovi v septembri 1944 úspešne prešiel aj d'alší návrh, a to udelenie čestného občianstva jeho priatel'ovi, ministrovi národnej obrany Štefanovi Haššíkovi (táto iniciatíva sa zrodila asi polroka pred udelením tejto pocty, teda $\mathrm{v}$ čase, ked' Haššík zastával funkciu nitrianskeho župana). ${ }^{113}$ Možno usudzovat', že Mojtov odmeraný postoj k Haššíkovi nebol len odrazom oportunizmu typického pre l'udáckych konzervatívcov, ktorý odrážal dojmy z obratu vývoja na frontových bojiskách, ale jeho konzistentnost' možno pozorovat' už od počiatkov ich spoločného pôsobenia v Nitre.

Na konci druhej svetovej vojny Mojto odmietol evakuovat' nielen mestský úrad a zoborskú školu, ale aj svoju rodinu. Pokúšal sa dosiahnut', intervenovat', aby vojaci neopevňovali nitriansky hrad, aby sa nestal opevnenou pozíciou a teda objektom ostrel'ovania. V tejto záležitosti intervenoval u ministra Haššíka, prezidenta aj nemeckého generála Hermanna Höfleho. Zabránil tiež nemeckým vojakom použit’ zoborský kostolík ako pozorovatel'ňu. U činitel'ov Slovenského kríža sa snažil dosiahnut', aby bola Nitra ako nemocničné mesto vyhlásená za otvorené mesto, čím by bola ochránená od vojenských operácií. Bol členom komisie, ktorá intenzívne podporovala žiadosti o oslobodenie spod opevňovacích prác. ${ }^{114}$ Pred Nemcami zachránil zariadenie nitrianskej plynárne a vodárne a ukryl mestský inventár, aby ho neodviezli. Z toho istého dôvodu dal zamurovat' inventár školy. U vládnych činitel'ov ${ }^{115}$ a osobne aj na Gestape tiež intervenoval proti zaist'ovaniu občanov, varoval nemecké velitel'stvo pred udavačmi a žiadal ho, aby zachovávalo l'udskost'. Rodinám odvlečených odbojárov Jána Sopóciho, Vojtecha Vlasáka a Jána Mrvu, ktorí pracovali v mestských službách nechal vyplácat’ nad'alej výplaty. S jeho vedomím a finančnou podporou boli počas nemeckej okupácie v Mestskom dome ukrytí ôsmi Slováci, ktorých prenasledovali Nemci. Domáhal sa aj ukončenia väzby viacerých účastníkov SNP, niektorým aj vydával

\footnotetext{
112 SNA, f. NS, šk. 3, OnL’ud 7/45-11.

113 SNA, f. NS, šk. 3, TnL’ud 4/45-38.

${ }^{114}$ Bližšie pozri: HALLON, Ludovít: Nasadenie civilného obyvatel'stva na opevňovacie práce 1944 - 1945. In: HALLON, Luudovít - MIČKO, Peter et al.: Vzostup a pád hospodárskeho vývoja Slovenska 1942 - 1945. Bratislava : Veda, 2019, s. 365-396.

115 Počas zimy 1944/1945 verejne interpeloval Haššíka, aby sa postaral o to, aby boli nitrianski politickí väzni prepustení z Ilavy, Serede a z miestnej väznice Gestapa. SNA, f. NS, šk. 3, TnL'ud 4/45-52.
} 
obecné svedectvá, aby sa mohli vrátit' po odvlečení z Nemecka. ${ }^{116}$ Vzhl'adom na nebezpečenstvo náletov aktívne pomáhal miestnej štátnej správe s prípravou rôznych opatrení $v$ rámci protileteckej ochrany a zažil aj tragické bombardovanie Nitry sovietskymi bombardérmi 26. marca 1945, pri ktorom v meste zahynulo 345 obyvatel'ov. Následne pomáhal s koordinovaním záchranných prác.

Bezprostredne po prechode fontu 3. apríla 1945 dočasne prebral vedenie mesta miestny národný výbor na čele s komunistom Jánom Schultzom. Prítomnost' sovietskych vojsk pomohla komunistom k obsadeniu 21 kresiel v 38-člennom výbore, 17 členov bolo kooptovaných demokratickým blokom. Z hl'adiska sledovanej témy je dôležitým faktom, že členmi najužšieho vedenie MNV (prvým podpredsedom a prvým tajomníkom) boli členovia predvojnového nitrianskeho poslaneckého zboru. ${ }^{117}$ Politická kariéra Františka Mojta sa tým uzavrela.

Obecná samospráva bola najnižšou zložkou verejnej správy. Vyššie uvedené údaje bude potrebné v budúcnosti detailnejšie doplnit' aj o načrtnuté interakcie s ostatnými prítomnými inštitúciami, do ktorých sa vedenie mesta prirodzene dostávalo v rámci svojej pôsobnosti. Predovšetkým šlo o miestne orgány štátnej správy. Podl'a súdobej legislatívy politickú a hospodársku agendu mesta kontroloval okresný úrad, ktorý dohliadal aj na štátne notárstvo ${ }^{118}$, žandárske stanice, povol'oval verejné zhromaždenia, kultúrne akcie, politické schôdze a i. ${ }^{119}$ Ako už bolo spomenuté, od konca roka 1938 sa začala presadzovat' silnejšia centralizácia a po nadobudnutí účinnosti zákona č. 190/1939 S. z. prešla dozorná pôsobnost' nad obcami na župný úrad, v ktorom sa vystriedali dvaja agilní zástupcovia režimu Andrej Dudáš a Štefan Haššík. Zaujímavé by mohli byt' poznatky o vzt'ahoch s regionálnymi zástupcami HSL'S a Hlinkovej gardy, ${ }^{120} \mathrm{~s}$ cirkevnými predstavitel'mi, armádnymi dôstojníkmi, hospodárskymi elitami a pod.

\footnotetext{
116 SNA, f. NS, šk. 3, TnL’ud 4/45-6.

117 Nezmenili to ani nové vol'by MNV 6. mája 1945, po ktorých sa pomer ešte viac prevážil na stranu komunistického bloku (24:18) a na čelo MNV sa dostali len zástupcovia Komunistickej strany Slovenska. Pamätná kniha mesta Nitry II., s. 130-131.

118 Po penzionovaní Antona Bučka 1. apríla 1938 zastával túto funkciu Viktor Fuzek, dovtedajší vedúci notár v Zlatých Moravciach. V rokoch 1939 - 1940 bol notárom Bohdan Vilček (od apríla 1943 okresný velitel' Hlinkovej gardy), po ňom Ján Pelikán. Pamätná kniha mesta Nitry II., s. 89.

119 Politickú a hospodársku agendu mesta kontroloval nitriansky okresný úrad, na čele ktorého stál od jeho kreovania v roku 1923 až do začiatku roka 1939 Rudolf Haláchy. Počas slovenského štátu sa v tejto pozícii vystriedali Vojtech Kabát, Ján Beňovský (1940 - 1944) a Štefan Fabián (1944 - 1945).

120 Či už so župným predsedom HSL'S a velitel’om Hlinkovej gardy Rudolfom Turčekom (župný a okresný lekár, od júna 1943 šéfredaktor Nitrianskej stráže), obvodnými tajomníkmi HSL'S Vojtechom Višňovským (bol aj oblastným velitel'om Hlinkovej gardy) a Jozefom
} 


\section{Martin Hetényi}

Dňa 23. apríla 1945, teda necelý mesiac po oslobodení mesta zaistili Mojta príslušníci Národnej bezpečnosti. V dôsledku súdneho procesu pred Národným súdom v Bratislave prišiel o akýkol'vek príjem, ked’že ho povereníctvo školstva a osvety svojim výnosom z 3. decembra 1945 suspendovalo z jeho učitel'ského zamestnania. ${ }^{121}$ Žaloba sa týkala trestných činov podl'a §2, 3 a 5 nar. č. 33 /1945 Zb. n., ${ }^{122}$ najmä členstva Františka Mojta v Štátnej rade, ${ }^{123}$ stotožňovania sa s politikou nacistického režimu vo verejných prejavoch a článkoch a neprimeraného obohatenia sa v členstvách správnych rád v spomínaných podnikoch. Žalobu obžalobca potom 30. júla 1946 rozšíril aj o jeho členstvo v redakčnej rade časopisu Nitrianska stráž, v ktorom publikoval a spolu s inými ho mal redigovat' v duchu pronacistickej a separatistickej politiky HSL'S. ${ }^{124}$ Bodom obžaloby bolo tiež predsedanie zasadnutiu mestského výboru dňa 24. septembra 1944, na ktorom sa rozhodlo o udelení čestného občianstva Nitry Štefanovi Haššíkovi, ktorý viedol operácie Domobrany a pohotovostné oddiely Hlinkovej gardy proti povstalcom. ${ }^{125}$ Súd ho odsúdil na nepodmienečný trest odňatia slobody 8 mesiacov, stratu občianskych práv na 5 rokov a konfiškáciu majetku. ${ }^{126}$ Sudcovia vzali do úvahy pol’ahčujúce okolnosti, a to jeho zásluhy v protinacistickom boji a záchranu politicky, národne a rasovo prenasledovaných obyvatel'ov. Dôvodom miernejšieho trestu bola aj dovtedajšia bezúhonnost' a ohl'ad na početnú rodinu, skutkové

Paučom (od júla 1939), predsedom miestnej organizácie HSL’S a zároveň predsedom Krajského súdu Jánom Rybárikom, oblastným velitel’om Hlinkovej mládeže Michalom Karvašom (riaditel' obchodnej akadémie v Nitre), miestnymi členmi HSL'S, Hlinkovej gardy a Hlinkovej mládeže.

120 SNA, f. NS, šk. 3, TnL’ud 4/45-5.

121 SNA, f. NS, šk. 3, TnL’ud 4/45-33.

122 FEDORČÁK, Peter: Proces s Vojtechom Tukom v roku 1946. In: Človek a spoločnost', 2015 , roč. 18, č. 4 , s. 43.

${ }^{123}$ Zo žalobného spisu: „... a tak $v$ tejto funkcii stal sa nástrojom fašistického a separatistického režimu, ktorý súhlasil s činnost'ou snemu a vlády a schval'oval politickú líniu režimu a tým mu dodával pred verejnost'ou vážnosti."SNA, f. NS, šk. 3, TnL’ud 4/45-39. Retribučné trestné stíhanie sa dotklo všetkých členov Štátnej rady. Bezpečnostné orgány obnoveného československého štátu sa bezprostredne po prechode frontu snažili zatknút' a uväznit' všetkých predstavitel'ov najvyšších ústavných orgánov slovenského štátu, vrátane Štátnej rady. Postačoval na to samotný fakt členstva $v$ danom orgáne, pričom právna kvalifikácia ich činov sa zväčša riešila až dodatočne formálnym podaním trestného oznámenia. Prepustenie z väzby súd dlho odmietal, často aj napriek zlému zdravotnému stavu vyšetrovaných. Viacerí takto strávili vo vyšetrovacej väzbe takmer dva roky, hoci niektorých nakoniec zbavili obžaloby. Ako upozorňuje historik Ondrej Podolec, členov vybrali do dvoch hlavných retribučných procesov na základe výšky predpokladaného udeleného trestu. PODOLEC, 0.: Retribučné procesy, s. 3-23.

${ }^{124} \mathrm{~V}$ praxi bol len formálne členom redakcie, o čom podl'a jeho tvrdenia ani nemal vedomost', pričom sa nezúčastnil ani jednej porady redakcie. SNA, f. NS, šk. 3, TnĹud 4/45-52.

125 SNA, f. NS, šk. 3, TnLud 4/45-39.

${ }^{126}$ SNA, f. NS, šk. 3, TnL'ud 4/45-57. 
priznanie a jeho antinemecký postoj. Ked’že už strávil vo väzniciach takmer 8 mesiacov (23. apríla - 22. septembra 1945, potom od 15. júna 1946), na slobodu bol prepustený krátko po vynesení rozsudku 16. septembra 1946. ${ }^{127}$ František Mojto žil v ústraní a zomrel 11. januára 1971.128

Záver. Štúdium politicky vplyvných elít včlenené do hlavného prúdu politológie je dnes mimoriadne prít’ažlivé aj pre historickú vedu. Z prezentovaného prehl'adu je očividné, že postavenie nitrianskych politických elít bolo v krízových časoch komplikované a problematické. Prípadová štúdia, ktorá zachytáva pôsobenie a procesy výmeny čelných predstavitel'ov väčšieho slovenského mesta a ktorých následkom bol rozvoj či stagnácia mesta a jeho osadenstva to zretel'ne naznačuje. Poznávanie charakteru politických elít, ich legitimita, praktické politické rozhodnutia a schopnosti umožňujú detailnejšie pochopit' i celkový rozsah uplatňovania demokratických či totalitných princípov riadenia v konkrétnych vývojových fázach. Na základe vyššie uvedených údajov možno konštatovat', že na príklade Františka Mojta môžeme explicitne pozorovat' pozoruhodné spôsoby v procese odovzdávania moci či spolupráce politických činitel’ov na všetkých stupňoch štátneho a straníckeho aparátu. Zároveň nám jeho prípad signalizuje personálnu kontinuitu s demokratickou ČSR, ktorá ale bola na celoslovenskej úrovni skôr výnimkou ako pravidlom. Hoci sa zmenil spôsob výberu predstavitel'ov mesta, ked' boli volené orgány nahradené menovaným vedením, určitým dôvodom na zachovanie kontinuity bolo okrem členstva vo vládnucej strane politické prostredie, z ktorého nitriansky starosta pochádzal. Mojto bol už pred vlastnou politickou kariérou príslušníkom krest'ansky a nacionalisticky orientovaných učitel'ských kruhov, ktorého výrazne ovplyvňovali kontakty s politikmi občianskych politických strán a rešpektovanie politickej plurality. Vzhl'adom na schopnosti Františka Mojta riešit' úlohy diplomaticky a konštruktívne, ako aj na jeho prístupnost' k problémom l'udí na spodných priečkach spoločenskej hierarchie bol v medzivojnovom období prijatel'ný nielen pre vlastnú politickú stranu, ale aj pre širšie politické kruhy. Koniec roku 1938 priniesol do života obecnej samosprávy viaceré negatívne zmeny a hoci bola saturácia poslancov odstránených z obecného zastupitel'stva kooptovanými členmi HSL'S jednoznačným popretím demokratických princípov, v praxi sa Mojto usiloval v riadení mesta udržat' aspoň ich náznaky.

\footnotetext{
127 V tom čase 14-ročného Emila, 16-ročného Antona, obaja žiaci gymnázia v Nitre, 18-ročného Štefana, žiaka Vyššej priemyselnej školy v Bratislave, 20-ročnú Máriu, absolventku gymnázia v Nitre,

${ }^{128}$ Bližšie pozri: HETÉNYI, Martin: Súdny proces so starostom Nitry Františkom Mojtom. In: Studia Historica Nitriensia, 2021, roč. 25, č. 1, s. 1-10. V štúdii sú zverejnené čiastkové výsledky biografického výskumu F. Mojta.
} 


\section{Martin Hetényi}

Po výraznom zásahu nacistického Nemecka do vnútropolitických pomerov na Slovensku v lete 1940 došlo k nahradeniu nitrianskeho mestského zastupitel'stva a starostu novým orgánom - vládnym komisárom, ktorým bol menovaný Mojto. Predstavitelia HSL'S ho považovali za politicky lojálneho, rovnako aj členov poradného zboru, ktorých čast' bola kooptovaná z prostredia mimo politiky. Ani posledná fáza likvidácie volenej samosprávy z roku 1944 na tom nič nezmenila a Mojto ako stabilný l'udácky káder zostal chránencom Jozefa Tisa i cirkevných autorít. Mojto zastával najvyššiu pozíciu v nitrianskej mestskej samospráve počas dvoch protikladných režimoch v relatívne dlhom časovom rozpätí. Šlo o osobnost', v ktorej sa kombinoval akcent na stranícku príslušnost' s jeho pozíciou uznávanej osobnosti činnej v regionálnom školstve a verejnom živote mesta bezprostredne po svojom príchode do Nitry, čo mu na jednej strane zosilňovalo nielen jeho protežovanie v HSL'S, no na strane druhej aj zvyšovalo legitimizáciu vlastných politických rozhodnutí. Na rozdiel od tejto personálnej kontinuity, širší okruh mestskej politickej elity vykazoval výraznú mieru diskontinuity. Moc na obecnej úrovni - výrazne limitovaná štátnym a straníckym aparátom, bola výrazne zúžená a koncentrovaná na niekol'ko jedincov. Tieto faktory pod vplyvom zmien na najvyšších úrovniach po vyhlásení autonómie a prebratí moci HSL'S či po salzburských rokovaniach v lete 1940 zretel'ne potvrdzovali radikalizáciu verejného života a rast totalitných prvkov na Slovensku. 
Výsledok obecných volieb v Nitre roku 1931

\begin{tabular}{|c|c|c|c|}
\hline $\begin{array}{c}\text { Kandidujúca politická } \\
\text { strana }\end{array}$ & $\begin{array}{l}\text { Počet } \\
\text { hlasov }\end{array}$ & $\begin{array}{c}\text { Počet } \\
\text { mandátov }\end{array}$ & Poslanci \\
\hline $\begin{array}{l}\text { Československá } \\
\text { sociálnodemokratická } \\
\text { strana }\end{array}$ & 1662 & 8 & $\begin{array}{l}\text { Dr. V. Szilágyi, Ručev, } \\
\text { S. Meitner, M. Zachar, } \\
\text { E. Kára, Kubíček, } \\
\text { Schwarz, Erdélyiová }\end{array}$ \\
\hline $\begin{array}{l}\text { Krajinská } \\
\text { krest’ansko-socialistická } \\
\text { strana }\end{array}$ & 1653 & 8 & $\begin{array}{l}\text { J. Jedlička, Gyürky, } \\
\text { K. Szmida, B. Rolfesz, } \\
\text { F. Bárek, Széchényi, } \\
\text { Rusz, Szabo }\end{array}$ \\
\hline $\begin{array}{l}\text { Komunistická strana } \\
\text { Československa }\end{array}$ & 1486 & 7 & $\begin{array}{l}\text { Kubiš, J. Dostál, Ola- } \\
\text { chová, P. Verdunič, } \\
\text { Hrivnák, J. Ostertág, } \\
\text { Tomaschek }\end{array}$ \\
\hline $\begin{array}{l}\text { Hlinkova slovenská } \\
\text { l'udová strana }\end{array}$ & 1098 & 5 & $\begin{array}{l}\text { F. Mojto, Rovnianek, } \\
\text { Bednárik, I. Rečka, } \\
\text { Dr. Nýbl }\end{array}$ \\
\hline $\begin{array}{l}\text { Československá strana } \\
\text { národno-socialistická }\end{array}$ & 855 & 4 & $\begin{array}{l}\text { R. Kulišek, R. Šu- } \\
\text { michrast, Ing. Horá- } \\
\text { ček, Ing. Neumann }\end{array}$ \\
\hline $\begin{array}{l}\text { Židovská robotnícka } \\
\text { strana }\end{array}$ & 419 & 2 & Löffler, Krausz \\
\hline $\begin{array}{l}\text { Československá strana } \\
\text { lidová }\end{array}$ & 400 & 2 & Dr. Beňo, J. Bednárik \\
\hline $\begin{array}{l}\text { Židovská hospodárska } \\
\text { strana }\end{array}$ & 388 & 2 & S. Tausig, Vajda \\
\hline Občianska strana & 265 & 1 & Bársony \\
\hline Židovská strana & 242 & 1 & Dr. Berényi \\
\hline $\begin{array}{l}\text { Československá národná } \\
\text { demokracia }\end{array}$ & 201 & 1 & Dr. J. Svoboda \\
\hline Zoborská strana & 166 & 1 & Dr. Brežný \\
\hline $\begin{array}{l}\text { Republikánska strana } \\
\text { zemedelského a malorol-- } \\
\text { níckeho l'udu }\end{array}$ & 163 & 0 & \\
\hline $\begin{array}{l}\text { Remeselnícko-obchod- } \\
\text { nícka strana }\end{array}$ & 62 & 0 & \\
\hline
\end{tabular}

Zdroj: Pamätná kniha mesta Nitry II., s. 35-36. 
Martin Hetényi

Výsledok obecných volieb v Nitre v máji 1938

\begin{tabular}{|c|c|c|c|}
\hline $\begin{array}{c}\text { Kandidujúca politická } \\
\text { strana }\end{array}$ & $\begin{array}{l}\text { Počet } \\
\text { hlasov }\end{array}$ & $\begin{array}{l}\text { Počet } \\
\text { mandátov }\end{array}$ & Poslanci \\
\hline $\begin{array}{l}\text { Zjednotená krajinská } \\
\text { krest’ansko-socialistická } \\
\text { a mad'arská národná stra- } \\
\text { na a Henleinova strana }\end{array}$ & 2698 & 11 & $\begin{array}{l}\text { J. Jedlička, Gyürky, } \\
\text { K. Szmida, B. Rolfesz, } \\
\text { Ševčík, Michalík, Mo- } \\
\text { kossányi, Dr. Fekets, } \\
\text { V. Császár, Š. Paulé- } \\
\text { nyi, V. Remeš }\end{array}$ \\
\hline $\begin{array}{l}\text { Hlinkova slovenská } \\
\text { l'udová strana }\end{array}$ & 2140 & 9 & $\begin{array}{l}\text { Mojto, Rovnianek, } \\
\text { I. Rečka, V. Višňov- } \\
\text { ský, I. Chovan, I. To- } \\
\text { masta, Dr. Ďurček, } \\
\text { I. Dinka, I. Bobek }\end{array}$ \\
\hline $\begin{array}{l}\text { Československá sociálno- } \\
\text { demokratická strana }\end{array}$ & 2071 & 9 & $\begin{array}{l}\text { I. Sýkora, S. Meitner, } \\
\text { E. Kára, Kubíček, } \\
\text { Erdélyiová, Korgó, } \\
\text { Kopeček, Holka, } \\
\text { M. Guláš }\end{array}$ \\
\hline $\begin{array}{l}\text { Československá strana } \\
\text { národno-socialistická }\end{array}$ & 806 & 4 & $\begin{array}{l}\text { R. Kulišek, Dr. Š. Va- } \\
\text { lent, I. Švec, Ing. Ho- } \\
\text { ráček }\end{array}$ \\
\hline $\begin{array}{l}\text { Komunistická strana } \\
\text { Československa }\end{array}$ & 646 & 3 & $\begin{array}{l}\text { Tomaschek, Kmet'o, } \\
\text { G. König }\end{array}$ \\
\hline $\begin{array}{l}\text { Koalícia } 3 \text { židovských } \\
\text { strán }\end{array}$ & 628 & 2 & $\begin{array}{l}\text { Dr. Neumann, } \\
\text { I. Vajda }\end{array}$ \\
\hline $\begin{array}{l}\text { Republikánska strana } \\
\text { zemedelského a malorol'- } \\
\text { níckeho l'udu }\end{array}$ & 418 & 2 & $\begin{array}{l}\text { M. Miškóci, } \\
\text { T. Rožnay }\end{array}$ \\
\hline $\begin{array}{l}\text { Československá strana } \\
\text { lidová }\end{array}$ & 286 & 1 & Dr. Beňo \\
\hline Národné zjednotenie & 161 & 1 & A. Duda \\
\hline $\begin{array}{l}\text { Odborová strana } \\
\text { republikánska }\end{array}$ & 153 & 0 & \\
\hline Nár. soc. živnostníci & 143 & 0 & \\
\hline Slovenská národná strana & 90 & 0 & \\
\hline $\begin{array}{l}\text { Živnostníctva a majitelia } \\
\text { domov }\end{array}$ & 70 & 0 & \\
\hline $\begin{array}{l}\text { Občianska strana } \\
\text { krest'anských rol'níkov a } \\
\text { robotníctva }\end{array}$ & 49 & 0 & \\
\hline
\end{tabular}

Zdroj: Pamätná kniha mesta Nitry II., s. 89. 


\section{Prehl'ad nitrianskych starostov a ich zástupcov v medzivojnovej ČSR}

\begin{tabular}{|c|c|c|}
\hline Starosta & 1. miestostarosta & 2. miestostarosta \\
\hline $\begin{array}{l}\text { E. Šebesta } 1922-1923 \text {, } \\
\text { Čs. strana socialistická } \\
\text { a záujmových skupín }\end{array}$ & - & - \\
\hline $\begin{array}{l}\text { K. Cobori } 1923 \text { - 1931, } \\
\text { Občianska strana, HSL'S }\end{array}$ & $\begin{array}{l}\text { K. Klobusiczký } 1923 \text { - } \\
\text { 1927, KKSS } \\
\text { V. Szilágyi } 1927 \text { - 1931, } \\
\text { ČSSD }\end{array}$ & $\begin{array}{l}\text { J. Radó } 1923 \text { - 1925, } \\
\text { Židovská strana } \\
\text { K. Jelínek } 1926 \text { - 1927, } \\
\text { Židovská strana } \\
\text { K. Klobusiczký } 1927 \text { - } \\
\text { 1931, KKSS }\end{array}$ \\
\hline $\begin{array}{l}\text { V. Szilágyi } 1931 \text { - 1932, } \\
\text { ČSSD }\end{array}$ & $\begin{array}{l}\text { R. Kulišek } 1931 \text { - 1932, } \\
\text { ČSNS }\end{array}$ & $\begin{array}{l}\text { F. Bárek } 1931 \text { - 1932, } \\
\text { KKSS }\end{array}$ \\
\hline $\begin{array}{l}\text { F. Mojto } 1932-1940, \\
\text { HSL'S }\end{array}$ & $\begin{array}{l}\text { S. Meitner } 1932-1938 \text {, } \\
\text { ČSSD } \\
\text { B. Rolfesz } 1938 \text { - 1940, } \\
\text { ZMS }\end{array}$ & $\begin{array}{l}\text { J. Jedlička } 1932 \text { - 1938, } \\
\text { KKSS } \\
\text { A. Arnold } 1938 \text { - 1940, } \\
\text { ČSL }\end{array}$ \\
\hline
\end{tabular}

Zdroj: Štatistická ročenka mesta Nitry. Nitra : Okresné oddelenie Slovenského štatistického úradu v Nitre, 1969, s. 7.

\section{Vedenie mesta Nitra v slovenskom štáte 1940 - 1945}

\begin{tabular}{|c|c|}
\hline \multicolumn{2}{|r|}{$14.11 .1940-26.4 .1944$} \\
\hline $\begin{array}{l}\text { vládny komisár } \\
\text { F. Mojto }\end{array}$ & $\begin{array}{l}\text { poradný zbor } \\
\text { J. Závodný, M. Boleček, Dr. J. Rybárik, A. Valik, } \\
\text { Š. Jankula, J. Kaňuch, V. Boháč, V. Gregory, } \\
\text { Dr. Á. Gyürky }\end{array}$ \\
\hline \multicolumn{2}{|r|}{ 27. 4. $1944-2.4 .1945$} \\
\hline $\begin{array}{l}\text { mešt'anosta } \\
\text { F. Mojto }\end{array}$ & $\begin{array}{l}\text { mestský výbor } \\
\text { V. Hrevsík, K. Novák, P. Hudec, Dr. V. Skyčák, } \\
\text { J. Rečka }\end{array}$ \\
\hline
\end{tabular}

Zdroj: Pamätná kniha mesta Nitry II., s. 97, 117. 